\title{
Afforestation for climate change mitigation: Potentials, risks and trade-offs
}

\author{
Jonathan C. Doelman ${ }^{1,2}$ (D) | Elke Stehfest ${ }^{1}$ (D) | Detlef P. van Vuuren ${ }^{1,2}$ (D) | Andrzej Tabeau ${ }^{3}$ | \\ Andries F. Hof ${ }^{1,2}$ (D) | Maarten C. Braakhekke ${ }^{4}$ | David E. H. J. Gernaat ${ }^{1,2}$ (D) | \\ Maarten van den Berg $^{1}$ | Willem-Jan van Zeist ${ }^{1}$ (D) | Vassilis Daioglou ${ }^{1,2}$ | \\ Hans van Meijl ${ }^{3}$ (D) | Paul L. Lucas ${ }^{1,2}$ (i)
}

${ }^{1} \mathrm{PBL}$ Netherlands Environmental Assessment Agency, The Hague, The Netherlands

${ }^{2}$ Copernicus Institute for Sustainable Development, Utrecht University, Utrecht, The Netherlands

${ }^{3}$ Wageningen Economic Research, Wageningen University \& Research, The Hague, The Netherlands

${ }^{4}$ Wageningen Environmental Research, Wageningen University \& Research, The Hague, The Netherlands

\section{Correspondence}

Jonathan C. Doelman, PBL Netherlands Environmental Assessment Agency, P.O. Box 30314, $2500 \mathrm{GH}$ The Hague, The Netherlands.

Email: jonathan.doelman@pbl.nl

Funding information

European Union's Seventh Framework Programme

\begin{abstract}
Afforestation is considered a cost-effective and readily available climate change mitigation option. In recent studies afforestation is presented as a major solution to limit climate change. However, estimates of afforestation potential vary widely. Moreover, the risks in global mitigation policy and the negative trade-offs with food security are often not considered. Here we present a new approach to assess the economic potential of afforestation with the IMAGE 3.0 integrated assessment model framework. In addition, we discuss the role of afforestation in mitigation pathways and the effects of afforestation on the food system under increasingly ambitious climate targets. We show that afforestation has a mitigation potential of $4.9 \mathrm{GtCO}_{2} /$ year at 200 US $\$ / \mathrm{tCO}_{2}$ in 2050 leading to large-scale application in an SSP2 scenario aiming for $2^{\circ} \mathrm{C}\left(410 \mathrm{GtCO}_{2}\right.$ cumulative up to 2100 ). Afforestation reduces the overall costs of mitigation policy. However, it may lead to lower mitigation ambition and lock-in situations in other sectors. Moreover, it bears risks to implementation and permanence as the negative emissions are increasingly located in regions with high investment risks and weak governance, for example in Sub-Saharan Africa. Afforestation also requires large amounts of land (up to 1,100 Mha) leading to large reductions in agricultural land. The increased competition for land could lead to higher food prices and an increased population at risk of hunger. Our results confirm that afforestation has substantial potential for mitigation. At the same time, we highlight that major risks and trade-offs are involved. Pathways aiming to limit climate change to $2^{\circ} \mathrm{C}$ or even $1.5^{\circ} \mathrm{C}$ need to minimize these risks and trade-offs in order to achieve mitigation sustainably.
\end{abstract}

\section{KEYWORDS}

afforestation, climate change mitigation, food security, integrated assessment, land-based mitigation, negative emissions

\section{1 | INTRODUCTION}

Ambitious climate change mitigation scenarios aiming to limit global warming to $2^{\circ} \mathrm{C}$ or less require very rapid reductions in greenhouse gas (GHG) emissions (Clarke et al., 2014; van Vuuren et al., 2013). Even if stringent policies are adopted, it is likely that negative $\mathrm{CO}_{2}$ emissions will become indispensable to achieve the Paris Agreement climate goal as shown in many mitigation scenario studies (Rogelj et al., 2018; 
Van Vuuren, Hof, Sluisveld, \& Riahi, 2017; van Vuuren et al., 2018). The need for such negative emissions highlights the role of land use in the context of mitigation. While emissions from agriculture, forestry and other land use are responsible for around $24 \%$ of anthropogenic GHG emissions in 2010 (Smith, 2013), land use also plays a critical role in two key negative emission options. First, through the production of bioenergy in combination with carbon capture and storage (BECCS; Azar et al., 2010). Second, through the expansion of forest area (afforestation) increasing the storage of $\mathrm{CO}_{2}$ in terrestrial vegetation (Canadell \& Raupach, 2008). This study focuses on the role of afforestation in climate change mitigation, where we define afforestation to include afforestation as well as reforestation, both of which are defined by FAO's Forest Resource Assessment (FAO, 2018) as the establishment of forest through planting and/or deliberate seeding.

The economic potential of afforestation for climate change mitigation has been assessed before using dedicated forestry models and integrated assessment models (IAMs; Benítez, McCallum, Obersteiner, \& Yamagata, 2007; Calvin et al., 2014; Humpenöder et al., 2014; Kindermann et al., 2008; Sathaye, Makundi, Dale, Chan, \& Andrasko, 2006; Sohngen \& Sedjo, 2006; Strengers, Minnen, \& Eickhout, 2007). Estimates vary widely depending on model characteristics and scenario assumptions, with cumulative sequestration until the year 2100 ranging from $176 \mathrm{GtCO}_{2}$ using $231 \mathrm{Mha}$ of land at $\$ 220 / \mathrm{tCO}_{2}$ (Sathaye et al., 2006) to $700 \mathrm{GtCO}_{2}$ using $2,800 \mathrm{Mha}$ of land at $\$ 1,165 / \mathrm{tCO}_{2}$ (Humpenöder et al., 2014). Other studies use more data-driven approaches, for example, Busch et al. (2019) who use data on agricultural prices and data on forest conversion from satellites to estimate a potential of $15.1 \mathrm{GtCO}_{2}$ in 2050 at $\$ 50 / \mathrm{tCO}_{2}$. Most studies find that already at low $\mathrm{CO}_{2}$ prices $\left(<\$ 50 / \mathrm{tCO}_{2}\right)$ afforestation is economically feasible. However, the wide range in results indicates it is very uncertain at what scale and at what costs afforestation is feasible.

Recent studies by Griscom et al. (2017), Lewis, Wheeler, Mitchard, and Koch (2019) and Bastin et al. (2019) that looked into the biophysical potential of afforestation using data-driven approaches received a lot of attention. They find high potentials: Griscom et al. (2017) present a sequestration rate of $10.3 \mathrm{GtCO}_{2}$ /year using 678 Mha by 2030 , Lewis et al. (2019) find $154 \mathrm{GtCO}_{2}$ on 350 Mha over a time period of 70 years, and Bastin et al. (2019) show a potential of $752 \mathrm{GtCO}_{2}$ using 900 Mha without specifying a time period. These studies state that afforestation is a major solution to climate change, however, they do not assess costs of afforestation or how it compares to other mitigation options. Moreover, they assume that afforestation-despite its large extent-does not occur on agricultural areas and thus does not affect food security. This highlights a fundamental divide in afforestation studies concerning the areas assumed to be available for afforestation.

Estimates in the literature show that the largest share of afforestation potential lies in tropical regions (Benítez et al., 2007; Griscom et al., 2017; Kreidenweis et al., 2016). The tropical regions are dominated by developing countries with high investment risks and weak governance implying substantial risk to the success of mitigation policies (lyer et al., 2015). Despite these risks, afforestation is a negative-emission technology that plays a crucial role in many existing scenarios aiming for $2^{\circ} \mathrm{C}$ or $1.5^{\circ} \mathrm{C}$ (Riahi et al., 2017; Rogelj et al., 2018). Calvin et al. (2014) show for one stylized scenario that large-scale afforestation reduces cumulative mitigation policy costs but also diminishes mitigation efforts in energy and industry. Otherwise, the policy implications and risks of afforestation in mitigation pathways received little attention.

Large-scale afforestation requires land that is most likely also needed to provide other land-based services such as food production. As a consequence, food security may be affected. Food security is defined by the FAO by four dimensions: availability (i.e. sufficient quantities of food), access (i.e. adequate resources to obtain food), utilization (i.e. nutritious and safe diets) and stability (i.e. the temporal dimension of the other three dimensions; FAO, 2008). When considering a role for afforestation in climate change mitigation, it is crucial to take the trade-off with food security into account. A number of studies have assessed the food security effects of land-based mitigation including bioenergy production, taxing of agricultural emissions and in some cases afforestation (Frank et al., 2017; Hasegawa et al., 2015, 2018; van Meijl et al., 2018). These studies indicate that landbased mitigation can put severe pressure on food security, however, the extent to which this can be ascribed to afforestation remains unclear. Kreidenweis et al. (2016) do show that large-scale afforestation can lead to a fourfold increase in global food prices, an indicator of access to food. However, the effect on other dimensions of food security is not discussed. Explicitly addressing food security risks is key if afforestation is considered in mitigation strategies.

Here we assess the global economic potential of afforestation for climate change mitigation in increasingly ambitious mitigation scenarios following the SSP-RCP scenario framework (van Vuuren et al., 2012) using the IMAGE 3.0 model framework (Stehfest et al., 2014). We present regional marginal abatement cost (MAC) curves that are based on grid-level forest growth potentials from the LPJmL model, region-specific estimates of afforestation costs, cost effects of land scarcity and risk-adjusted investment decisions. Our approach provides a new estimate of afforestation potential to the literature with high geographic detail. The presented approach is coupled with the climate policy model FAIR-SimCAP (den Elzen, Lucas, \& Vuuren, 2008) and the energy simulation model TIMER (Van Vuuren, 2007). This integration makes it possible to compare afforestation to a large number of other climate change mitigation options in the energy, industry and agricultural sectors, and is used to analyse how and to what extent afforestation changes mitigation pathways. Next to that, the approach is coupled to the agro-economic model MAGNET Woltjer and Kuiper (2014) and the health model GISMO (Lucas et al., 2019). This is used to provide a detailed analysis of the potential effects of afforestation on food security, which is assessed along two dimensions of the FAO definition of food security (FAO, 2008): For access to food we present the indicator food price, and for availability of food we assess food availability per capita and the number of people at risk of hunger. Compared to the existing literature our study focuses on the isolated effects of afforestation on mitigation pathways and food security. In this way we provide a detailed assessment of the risks and trade-offs of this mitigation strategy, which is an important component in many scenarios aiming to prevent dangerous climate change. 
In Section 2 a detailed description of the methodology to model afforestation and how the approach is integrated in the IMAGE framework is provided, followed by an overview of the implemented scenarios. Section 3 presents the mitigation potential of afforestation, analyses the emission trajectories in the mitigation scenario, and shows resulting land-use dynamics and food security effects. Where possible, results are presented for 10 aggregated regions (see Table S1). Furthermore, a sensitivity analysis is presented investigating the number of crucial variables as well as uncertainty related to climate change and $\mathrm{CO}_{2}$ fertilization. Finally, Section 4 reflects on the methodology and results, compares results to existing literature and summarizes conclusions.

\section{2 | MATERIALS AND METHODS}

\section{1 | The IMAGE model framework}

Our analysis is performed with the IMAGE $3.0^{1}$ integrated assessment modelling framework. The IMAGE framework is used to simulate interactions between human activities and the environment to explore long-term global environmental change and policy options in the areas of climate, land use and sustainable development (Stehfest et al., 2014). It comprises a number of submodels describing land use, the agricultural economy, the energy system, natural vegetation, hydrology and the climate system (Figures S1 and S2). Agriculture, forestry and land-use dynamics are modelled on the grid-level in the IMAGE-Land Management land use model (Doelman et al., 2018). Demand for crop and livestock products, and trends in agricultural intensification and trade dynamics are provided by the computable general equilibrium model (CGE) MAGNET (Woltjer et al., 2014). Gridded land-use dynamics are implemented in the dynamic global vegetation model LPJmL to model effects on the carbon and hydrological cycle (Bondeau et al., 2007; Sitch et al., 2003). LPJmL provides data on potential crop and grass yields, land-use change emissions and irrigation water use. The simulation model TIMER represents the energy system with high technological detail for 12 primary energy carriers including bioenergy (Van Vuuren, 2007). The demand for bioenergy is determined by TIMER based on grid-level land availability in IMAGE-LandManagement. GHG emissions from energy, industry and land use are inputs to the simple climate model MAGICC, which emulates complex climate models to calculate global mean temperature change (Meinshausen, Raper, \& Wigley, 2011). The climate policy model FAIR-SimCAP uses MAC curves to determine costoptimal emission pathways to achieve specific climate targets (den Elzen et al., 2008). Finally, data on food availability, energy use and climate change are input to the GISMO model, which calculates changes in human development in relation to the global environment (Lucas et al., 2019).

${ }^{1}$ For more background info, see the detailed, online IMAGE documentation: http://thema sites.pbl.nl/models/image/index.php/Welcome_to_IMAGE_3.0_Documentation.

\section{2 | Overview of afforestation method}

To investigate afforestation as a climate change mitigation option data from different submodels of the IMAGE framework is used (Figure 1). The biophysical potential of forest growth is provided by LPJmL (Section 2.3). Current and projected land use in a baseline scenario is provided on a grid-basis by IMAGE-LandManagement (Section 2.5). The value of agricultural land use is taken from the agro-economic model MAGNET (Woltjer \& Kuiper, 2014; Section 2.4.1), and other cost components are taken from sources in the literature (Section 2.4.2).

To calculate if and how much afforestation takes place in a scenario, these data are combined as follows: It is assumed that cropland, pasture and degraded forest land as projected in a baseline scenario are available for afforestation. For each grid cell $(5 \times 5$ arc-minutes) in each time step (5 years) during the scenario period (2010-2100), a comparison is made whether it is more profitable to use the land for agriculture or to afforest for climate change mitigation. Climate change mitigation policy is driven by a global $\mathrm{CO}_{2}$ price. To determine the profitability of an investment, it is common to calculate the net present value (NPV). This is the present value of all future cash flows subtracted by the present investment costs, opportunity costs and other costs (Clarke, McGugin, Schmirer, \& Towers, 2008; Shabman, Zepp, Wainger, \& King, 2002). The NPV is calculated using Equation (1):

$\mathrm{NPV}_{i}=\sum_{t=1}^{T} \frac{\left(\text { Csegrev }_{i, t}-\text { landrent }_{i, t}-\text { monitorcost }_{i, t}\right)}{(1+r)^{t}}-$ conversioncost $_{i}$,

where NPV is the NPV at location $i$ at time step $t$; Cseqrev is the annual revenue of carbon sequestration, which is the product of the $\mathrm{CO}_{2}$ price and the carbon stored annually in the vegetation and soil; landrent is the annual economic return to land for agricultural land use (crop or livestock production), which is assumed as the opportunity cost and depends on the amount of afforestation in previous time steps (Section 2.4.1); monitorcost is the annually returning cost to monitor carbon stocks; conversioncost is the initial investment cost of afforestation that is required at the start of afforestation (conversion/preparation of the land and planting of trees; Section 2.4.2); $T$ is the time horizon, which is the period of time that is considered to determine the profitability of an investment. It is assumed to be 30 years, which is a common period for a carbon sequestration project to decide whether or not to invest (Humpenöder et al., 2014; Winsten, Walker, Brown, \& Grimland, 2011); $r$ is the discount rate. Instead of a uniform discount rate we use region-specific risk-adjusted discount rates to account for differences in investment risks between regions. These can be notably higher in developing regions that also have high afforestation potential (Benítez et al., 2007; lyer et al., 2015). World bank data on national lending rates is used as this represents the annual rate of return that is required for a landowner to make an investment profitable. A simple exponential relation between lending rates and GDP per capita for the period 1996-2015 is fitted to derive regional discount rates, resulting in a range of $6.3 \%$ in the United States to 20.7\% in Eastern Africa in 2010 (see SI Section 1 and Table S2). This relation is assumed to also hold in future periods. 


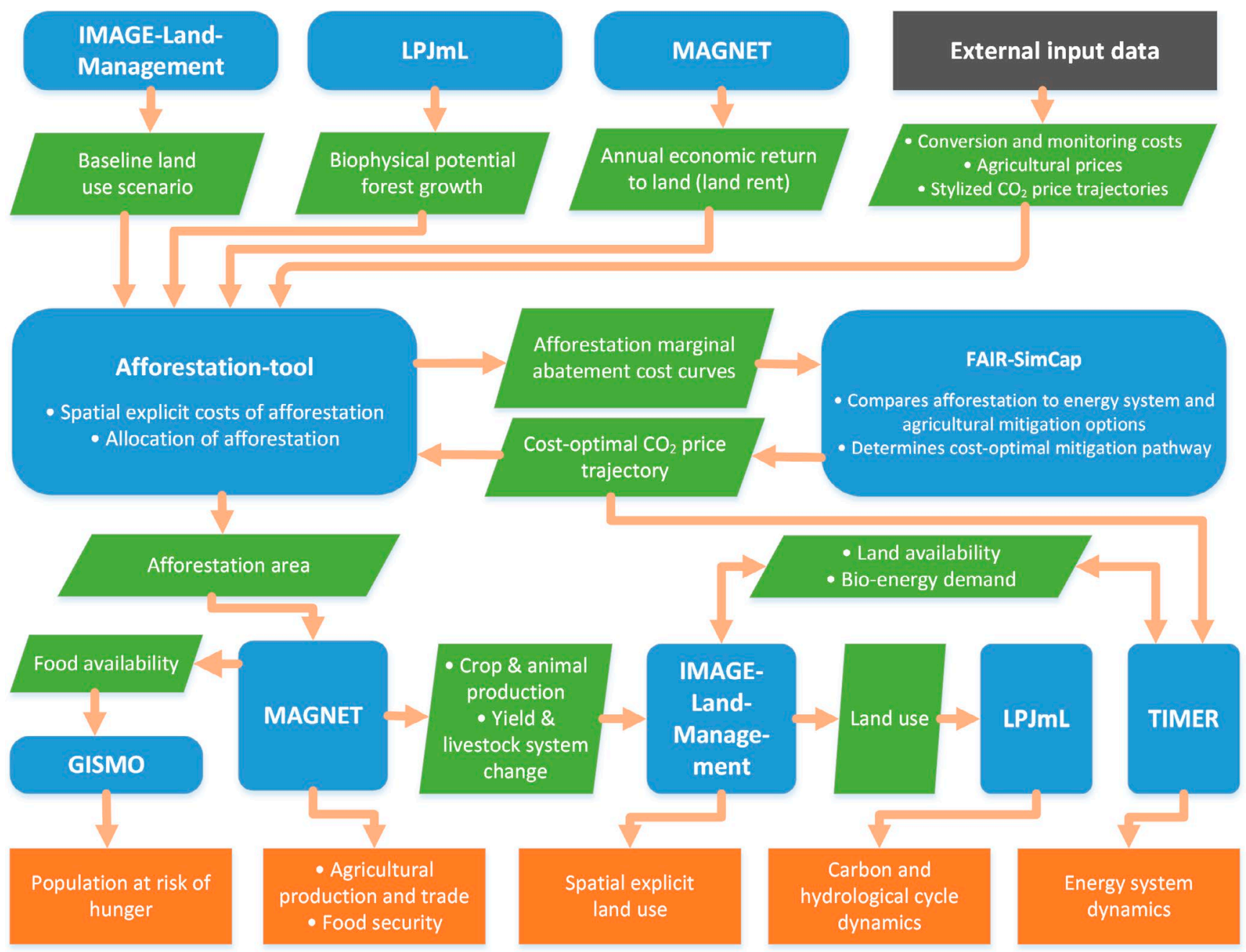

FIGURE 1 Schematic overview of afforestation modelling procedure [Colour figure can be viewed at wileyonlinelibrary.com]

Afforestation is assumed to take place if the investment is profitable, that is, if the NPV is positive. All grid cells that can potentially be afforested are sorted according to their NPV, and afforestation is allocated to the most profitable locations. Grid cells with average carbon sequestration of less than 0.5 ton $\mathrm{C} \mathrm{ha}^{-1}$ year $^{-1}$ during the first 30 years after planting are excluded to ensure forest growth can be sustained. Once forest is established it is not converted back to agriculture at a later point in time, thus excluding the risk of nonpermanence (Dutschke, 2001). To prevent unrealistically fast conversion of agricultural land to forest in case of very high $\mathrm{CO}_{2}$ prices, a maximum afforestation rate is assumed of $0.4 \%$ /year relative to total agricultural land, on a regional scale. This assumption represents a limit to the speed at which climate policy is adopted by (i.e. by landowners, policy makers, forestry experts). Limits to the rate of change in response to climate policies are observed, for example in bioenergy policies in the United Kingdom (Alexander, Moran, Rounsevell, \& Smith, 2013) and are also important assumptions in the modelling of different climate change mitigation policies (den Elzen et al., 2008). However, historically afforestation has not occurred at the scale investigated in this study. Therefore, the maximum afforestation rate is based on examples of expansion of palm oil in Indonesia and soy bean in Brazil that have shown rates of change in the order of magnitude as assumed here (see SI Section 2 and Figure S3). We test the impact of this critical assumption in a sensitivity analysis (Section 3.2.4).

We use a stand-alone tool (afforestation-tool) to calculate afforestation dependent on a prescribed $\mathrm{CO}_{2}$ price trajectory (Figure 1). First, stylized $\mathrm{CO}_{2}$ price trajectories are implemented to create MAC curves for afforestation that show regional mitigation achieved at increasing $\mathrm{CO}_{2}$ prices (SI Section 3). These MAC curves are then implemented in the FAIR-SimCAP model (den Elzen et al., 2008), which determines the cost-optimal $\mathrm{CO}_{2}$ price trajectory by comparing afforestation to other mitigation options (in the energy system and in agriculture) to achieve a predefined climate target (Section 2.5). The afforestation-tool is then used again to calculate the afforestation area of the cost-optimal $\mathrm{CO}_{2}$ price trajectory. This area is subsequently implemented in MAGNET, IMAGE-LandManagement and LPJmL to calculate effects on the food system, land use, carbon and hydrological cycles. Food availability from MAGNET is input to GISMO to determine the population at risk of hunger (see SI Section 4). The $\mathrm{CO}_{2}$ price trajectory from FAIR-SimCAP is implemented in TIMER to determine energy system dynamics. Bioenergy use is 
also determined by TIMER based on land availability from IMAGELandManagement assuming that only the other land that is not available for food production or afforestation is available for bioenergy production (Daioglou, Doelman, Wicke, Faaij, \& Vuuren, 2019; Hoogwijk, Faaij, Vries, \& Turkenburg, 2009). While this assumption implies that we do not capture interactions between food and bioenergy production, it does allow to compare afforestation to the energy system and emission dynamics of bioenergy use and to assess the direct effect of afforestation on food security.

\section{3 | Biophysical potential of afforestation}

Biophysical potential of forest growth on a grid-basis is modelled using LPJmL (Bondeau et al., 2007; Sitch et al., 2003; Figure 2). In this study we use the new forest plantation functional types (FPFT) that have been developed to represent planted forests (Braakhekke et al., 2019). Tree growth is simulated for three FPFTs (temperate, tropical and boreal). These are based on the natural plant functional types (PFTs) 'temperate broadleaved summergreen tree', 'tropical broadleaved evergreen tree' and 'boreal needle-leaved evergreen tree'. Compared to natural PFTs, a newly established FPFT stand has a high initial planting density representing the planting of forest saplings and prevention of competition with other plant species as opposed to the gradual establishment and natural succession assumed in natural PFTs. The growth rates of the FPFTs are calibrated to forest plantation data from the literature. In addition, constraints on carbon use efficiency and maximum biomass are used to ensure that carbon fluxes and storage are realistic compared to their natural counterparts. No forest management after establishment such as irrigation, fertilization or thinning is assumed. The resulting growth rates are

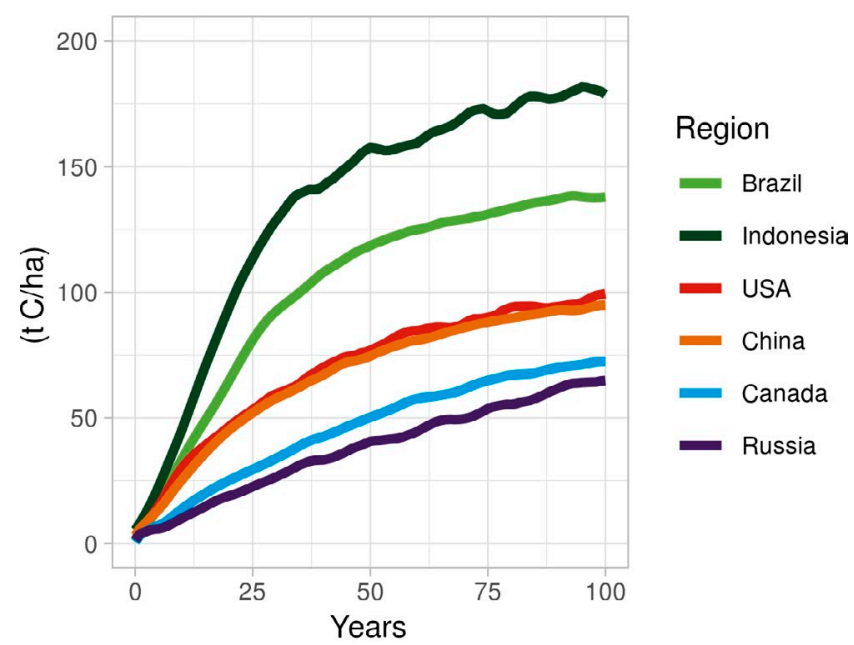

FIGURE 2 Potential average cumulative carbon sequestration of forest plantations on current agricultural land that can sustain forest growth ( $>0.5$ ton $C$ ha $^{-1}$ year ${ }^{-1}$ growth in first 30 years after planting) in six selected regions: two predominantly tropical regions (Brazil and Indonesia), two predominantly temperate regions (USA and China) and two predominantly boreal regions (Canada and Russia) [Colour figure can be viewed at wileyonlinelibrary.com] substantially higher than natural forest growth rates, but lower than intensively managed forest plantations (see for more info Braakhekke et al., 2019). Therefore, this representation of forest plantations can be described as a planted forest in line with the FAO definition (FAO, 2018) with minimal management after establishment.

\subsection{Costs of afforestation}

\subsection{1 | Opportunity costs}

An important component of the investment decision for afforestation (Equation 1) is the opportunity cost of land. In this study afforestation competes with agriculture. Therefore, the opportunity cost is the annual economic return to land of agriculture. We use here the opportunity costs as calculated by the CGE model MAGNET. MAGNET is an extension of the GTAP model and database (Hertel, 2012). GTAP has detailed information on the value added of the agricultural sector, which is distributed over the production factors land, labor and capital. The share of the value added related to land is the economic return to land from agriculture, also known as the land rent. Land rent from MAGNET is available at a resolution of 26 regions (Table S4) while afforestation is implemented at the grid-level. Therefore, a downscaling of land rent is applied using grid-based yields from LPJmL calibrated to FAOSTAT (FAOSTAT, 2017), and prices of IMAGE crop types and grass derived from World Bank, FAO and FAPRI data (Table S3).

MAGNET includes agricultural land as an explicit production factor described by a land supply curve (Woltjer \& Kuiper, 2014). The value of land rent changes in scenario projections due to various factors, for example, due to economic development and population growth leading to higher demand for agricultural products, due to substitution between land, labour and capital, or due to increasing scarcity of land as the additional land available for agriculture is depleted. These changes are included in the investment decision (Equation 1) and depend on location and time. MAGNET does not explicitly include afforestation. For the purpose of this study a model setup is developed in which agricultural land use in MAGNET can exogenously be reduced by a prescribed land area requirement, in this case for afforestation (Figure 3): The land supply curve is shifted to the left resulting in a new equilibrium leading to adjusted food prices, food consumption, trade and agricultural efficiency. To take the effect of increasing land rent into account in the afforestation decision, a set of stylized scenarios is created where agricultural land is linearly reduced. The land rent values from these scenarios are interpolated to create a detailed look-up table of land rents dependent on the reduction in agricultural land (Table S5). These are subsequently applied in the NPV calculation to include the effect of higher afforestation area on land rent.

\subsubsection{Conversion and monitoring costs}

A study by Winsten et al. (2011) focusing on afforestation specifically for carbon sequestration in the north-eastern United States, is used to 


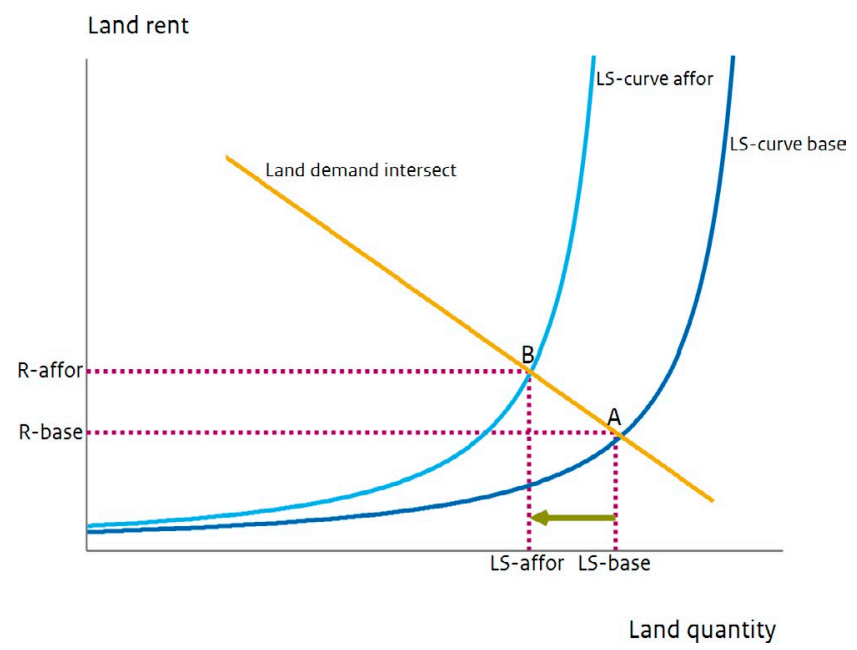

FIGURE 3 Graphic representation of agricultural land supply curves for a baseline and an afforestation scenario (LS-curve base in dark blue and LS-curve affor in light blue, respectively). The green arrow indicates a prescribed reduction in agriculture. The baseline scenario equilibrium land supply (LS-base) and land rent (R-base) in point $A$ shift following the land demand intersect (yellow) to a new afforestation scenario equilibrium land supply (LS-affor) and land rent (R-affor) in point B [Colour figure can be viewed at wileyonlinelibrary.com]

estimate conversion and monitoring costs. Winsten et al. (2011) sent questionnaires to foresters to investigate the costs of conversion. The conversion costs specifically comprise site preparation, planting, maintenance (e.g. mowing, weeding, herbicides, tilling, herbivore control), and replanting costs. In this study, we take the average value of these costs across all states considered in the Winsten study. Conversion costs are assumed to be an initial cost, that is, no additional future costs are taken into account. This is in line with the minimal forest management assumed in LPJmL (Section 2.3). Monitoring of carbon stocks to check if a land owner is eligible for carbon sequestration payments is estimated at $\$ 71.70$ per hectare for a 20 year project (Winsten et al., 2011). For this estimate, a discount rate of $4 \%$ was used, implying an annual cost of $\$ 5.25$ per hectare for the United States.

In order to use the data in other world regions we assume that $50 \%$ are capital costs from, for example, machine use or fence building that are considered to be equal globally. The other $50 \%$ are assumed to be labour costs depending on regional differences in wages for low-skilled labour. As a proxy for this, regional GDP/ capita relative to the United States is used. This results in total costs for conversion ranging from $\$ 862$ per hectare in Eastern Africa to $\$ 1,633$ per hectare in the United States (Table S4). While this is a simplistic procedure, the resulting cost range is similar to other studies (Humpenöder et al., 2014; Sathaye et al., 2006). The same method is applied to scale monitoring costs between regions resulting in the range of $\$ 2.66$ ha $^{-1}$ year $^{-1}$ in Eastern Africa to $\$ 5.25$ ha $^{-1}$ year $^{-1}$ in the United States. For the projection period, the costs of conversion and of monitoring for the United States are assumed to increase at the same rate as GDP/capita. In other regions, the development of GDP/ capita relative to the United States is used to scale costs (Table S6).

\section{5 | Scenario definitions}

A set of 11 scenarios is defined to investigate the role of afforestation in increasingly stringent mitigation scenarios (Table 1). The baseline scenario is the IMAGE 'middle of the road' SSP2 scenario (Vuuren, Stehfest, et al., 2017). Crucial drivers of SSP2 are population, which continues to grow until 2050 and shows a slight decrease from 2050 to 2100 , and GDP, which continues to grow in all regions until the end of the century (Figure S6). The developments in agricultural land are based on the interactions between projections of food demand, agricultural efficiency and the economy. Degraded forest estimates are derived from the historical difference in deforestation due to agricultural expansion and deforestation according to FAO's Forest Resource Assessment (for more detail see Doelman et al., 2018). The SSP2 baseline scenario results in a change in radiative forcing of around $6.5 \mathrm{~W} / \mathrm{m}^{2}$. To assess the effect of increasingly ambitious mitigation targets, the baseline is combined with a number of climate mitigation targets: $6.0 \mathrm{~W} / \mathrm{m}^{2}, 4.5 \mathrm{~W} / \mathrm{m}^{2}, 3.4 \mathrm{~W} / \mathrm{m}^{2}, 2.6 \mathrm{~W} / \mathrm{m}^{2}$ and $1.9 \mathrm{~W} / \mathrm{m}^{2}$ (Table 1). The first four scenarios correspond to the forcing targets of the RCP scenarios (van Vuuren et al., 2011), where $2.6 \mathrm{~W} / \mathrm{m}^{2}$ has a $66 \%$ likelihood to limit global warming to $2^{\circ} \mathrm{C}$ (Rogelj et al., 2011). The $1.9 \mathrm{~W} / \mathrm{m}^{2}$ target has a $66 \%$ likelihood to limit global warming to $1.5^{\circ} \mathrm{C}$ and reflects the ambitions expressed in the 2016 Paris Agreement (Rogelj et al., 2018). Next to the scenarios with afforestation, an additional set of scenarios with the same climate targets are defined as reference cases where afforestation is excluded as a mitigation policy. In all scenarios except the baseline, avoided deforestation policy is implemented under the assumption that this is cheaper than afforestation (based on Kindermann et al. (2008)): all forests with carbon stocks of $10 \mathrm{tC} /$ ha or higher are protected (Doelman et al., 2018; Overmars et al., 2014). We exclude climate impacts in this set of scenarios to improve interpretability of the results, but include it in the sensitivity analysis.

In addition, we define a number of sensitivity tests to investigate the importance of various parameter settings that are central to the afforestation methodology: the discount rates, the time horizon, the conversion and monitoring costs and the maximum afforestation rate. In addition, climate change effects with and without $\mathrm{CO}_{2}$ fertilization are tested (for details see Table S7). The sensitivity tests are implemented by rerunning a scenario with a predetermined $\mathrm{CO}_{2}$ price with one of the selected parameters changed in a positive or negative direction. We perform the sensitivity for three scenarios

TABLE 1 Description of implemented scenarios

\begin{tabular}{|lll|}
$\begin{array}{l}\text { Climate target (radiative } \\
\text { forcing, } \mathbf{W} / \mathrm{m}^{2} \text { ) }\end{array}$ & Afforestation & $\begin{array}{l}\text { No afforestation } \\
\text { (reference) }\end{array}$ \\
\hline No target & - & SSP2-baseline \\
\hline 6.0 & SSP2-6.0-A & SSP2-6.0-R \\
\hline 4.5 & SSP2-4.5-A & SSP2-4.5-R \\
\hline 3.4 & SSP2-3.4-A & SSP2-3.4-R \\
\hline 2.6 & SSP2-2.6-A & SSP2-2.6-R \\
\hline 1.9 & SSP2-1.9-A & SSP2-1.9-R \\
\hline
\end{tabular}


with different climate mitigation targets with increasing ambition: SSP2-4.5-A, SSP2-3.4-A and SSP2-2.6-A. The sensitivity is assessed by investigating the effect on cumulative carbon sequestration (2010-2100).

\section{3 | RESULTS}

\section{1 | MAC curves}

Our results show that there is moderate potential for climate change mitigation through afforestation at low prices: globally at US\$50/ $\mathrm{tCO}_{2}$ we find $0.75 \mathrm{GtCO}_{2}$ /year in 2030, $1.5 \mathrm{GtCO}_{2}$ /year in 2050 and $1.1 \mathrm{GtCO}_{2}$ /year in 2100 (Figure 4). More than half of the potential at low cost is located in Latin America, which is related to low land prices, high forest growth rates and relatively lower discount rates than other tropical regions with similarly high growth rates. In 2100 , the potential is lower than in 2050 due to higher costs related to continued economic growth and higher land prices because of increased land scarcity. The potential is lower in 2030 compared to 2050 due to limits on how fast afforestation area can expand.

The potential from afforestation increases substantially with higher $\mathrm{CO}_{2}$ prices: globally at $\mathrm{US} \$ 200 / \mathrm{tCO}_{2}$ there is a potential of 2.7 $\mathrm{GtCO}_{2}$ /year in 2030, $4.9 \mathrm{GtCO}_{2}$ /year in 2050 and $5.8 \mathrm{GtCO}_{2}$ /year in 2100. At these prices there is increased potential in temperate regions, notably North America and China with 0.6 and $0.5 \mathrm{GtCO}_{2}$ /year respectively in 2050. Afforestation is relatively more expensive in these regions due to high land prices and lower forest growth rates. The potential in Russia and Central Asia remains limited with 0.12
$\mathrm{GtCO}_{2}$ /year in 2050, which is caused by relatively low growth rates in boreal forests. At very high $\mathrm{CO}_{2}$ prices of over $\mathrm{US} \$ 500 / \mathrm{tCO}_{2}$ the potential increases slightly to $0.18 \mathrm{GtCO}_{2}$ /year (see Figure S5).

At all $\mathrm{CO}_{2}$ price levels, Latin America and Sub-Saharan Africa are responsible for at least $50 \%$ of the climate change mitigation potential from afforestation. This is mostly related to large land areas that can potentially be afforested, high forest growth rates and higher absolute carbon stocks that can be reached per land area compared to temperate or boreal forests (see Figure 2). While we do take into account higher risks of investment in these regions through risk-adjusted discount rates, this only affects the price at which afforestation becomes economically feasible but does not change the maximum potential.

\section{2 | Mitigation scenarios}

\subsection{1 $\mathrm{CO}_{2}$ emissions}

To achieve an ambitious mitigation target of $2.6 \mathrm{~W} / \mathrm{m}^{2}$ substantial reductions of emissions from the energy, industry and land sectors are implemented (Figure 5a). In addition, negative emissions from afforestation and BECCS are used to achieve the mitigation target. In the SSP2-2.6-A scenario afforestation is implemented as soon as mitigation policy starts (from 2020 onwards) as it is available at relatively low costs compared to other mitigation options. BECCS is implemented from 2030 onwards when $\mathrm{CO}_{2}$ prices have risen up to a level where the technology has become profitable. By the end of the century, negative emissions of $5.0 \mathrm{GtCO}_{2}$ /year and $3.1 \mathrm{GtCO}_{2}$ /year
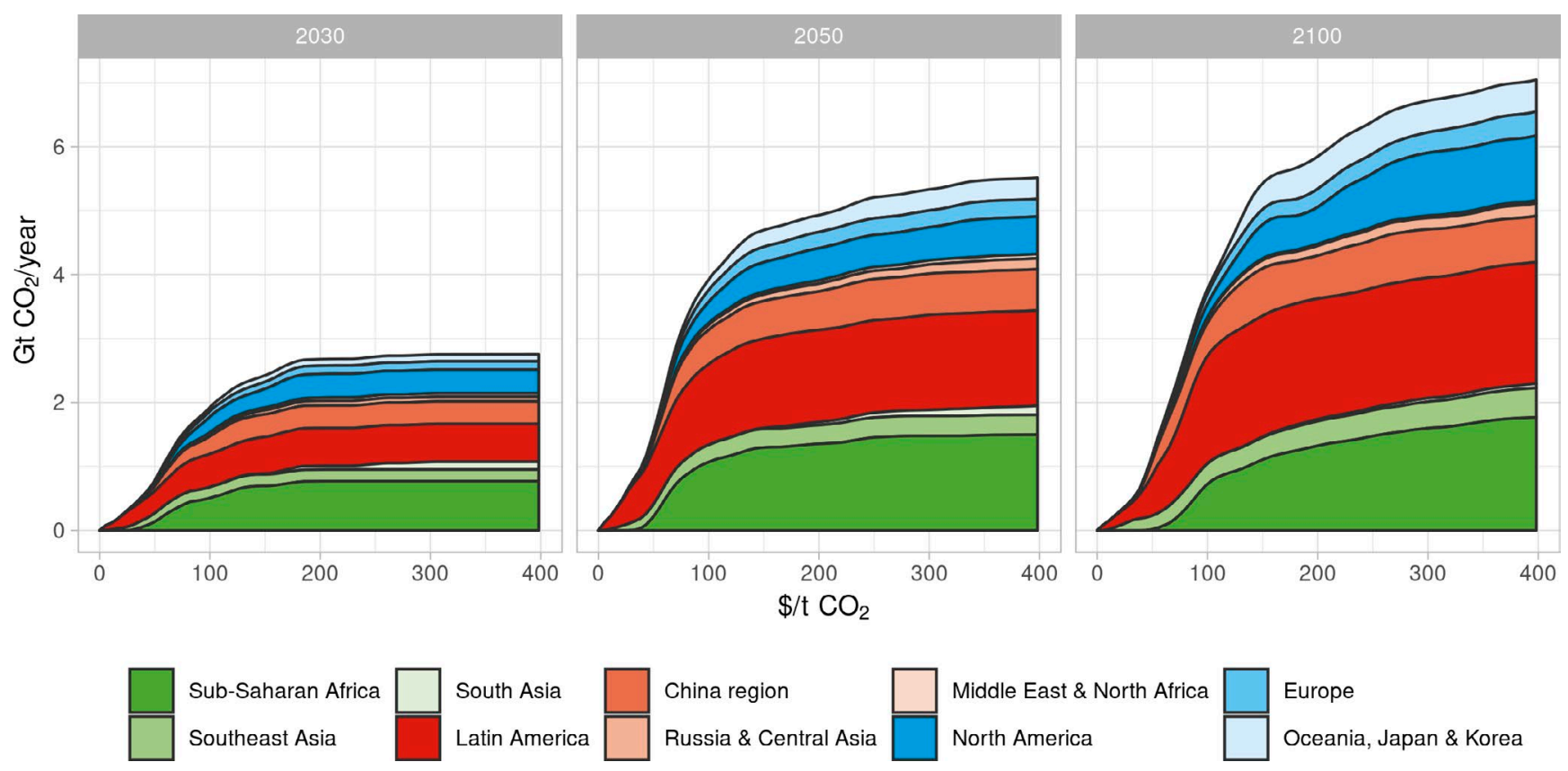
China region
Russia \& Central Asia

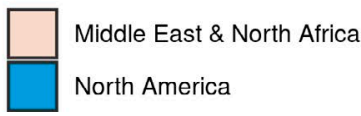

Europe

Oceania, Japan \& Korea

FIGURE 4 Marginal abatement cost (MAC) curves of carbon sequestration through afforestation in 10 aggregated regions (see SI Table 1) in years 2030, 2050 and 2100. Based on stylized linear $\mathrm{CO}_{2}$ price trajectories that increase from $0 / \mathrm{tCO}_{2}$ in 2020 to $\mathrm{CO}_{2}$ price as shown on the Y-axis in 2030, 2050 and 2100. For clarity, the graphs are limited to $400 \mathrm{US} / \mathrm{tCO}_{2}$. MAC curves up to $1000 \mathrm{US} / \mathrm{tCO}_{2}$ are $\mathrm{presented}$ in SI Figure 5 [Colour figure can be viewed at wileyonlinelibrary.com] 
(a) $\mathrm{CO}_{2}$ emissions - SSP2-2.6-A

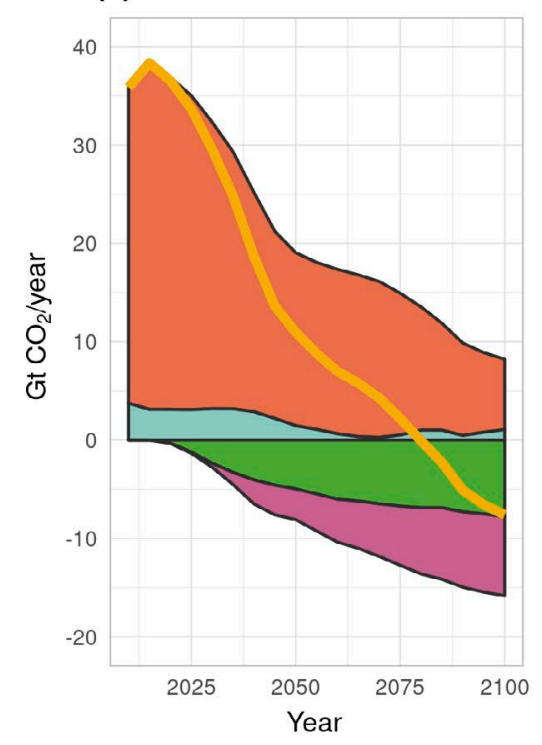

\begin{tabular}{ll}
\hline & Emissions energy and industry \\
\hline \hline & LUC/forestry emissions \\
\hline & BECCS negative emissions \\
\hline & Afforestation negative emissions
\end{tabular}

Net emissions (b) Cumulative $\mathrm{CO}_{2}$ emissions 2010-2100

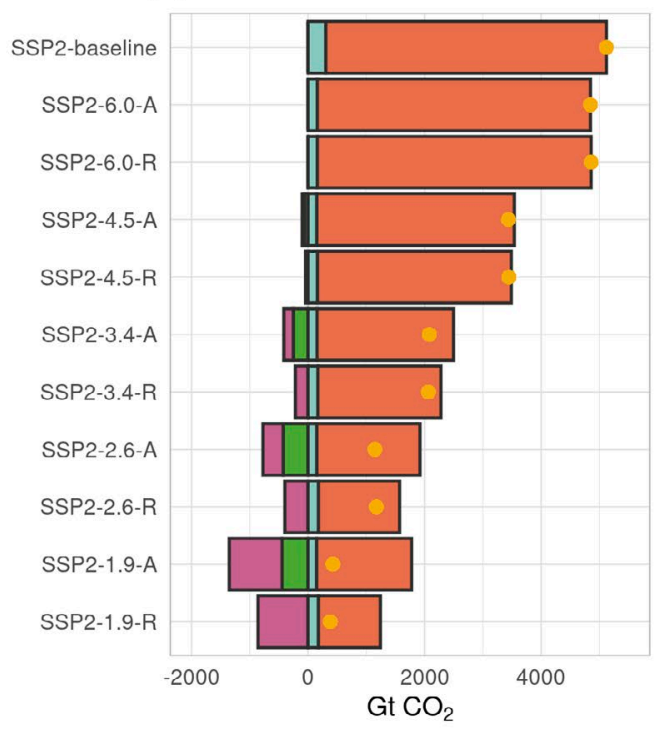

(c) $\mathrm{CO}_{2}$ price $2020-2100$

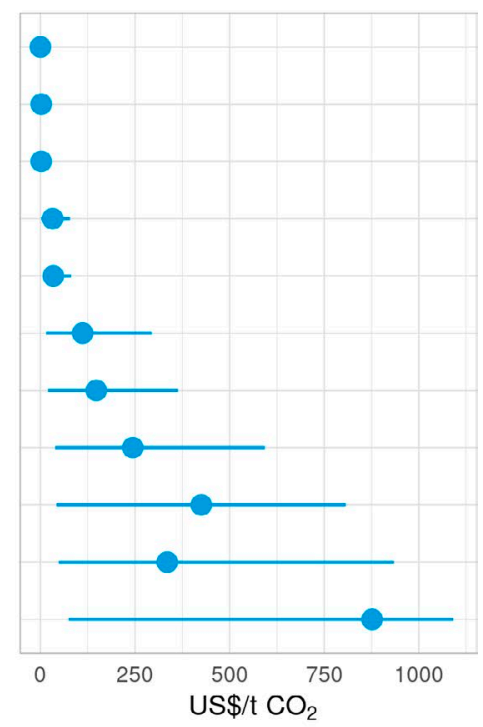

(d) Regional cumulative $\mathrm{CO}_{2}$ emissions 2010-2100

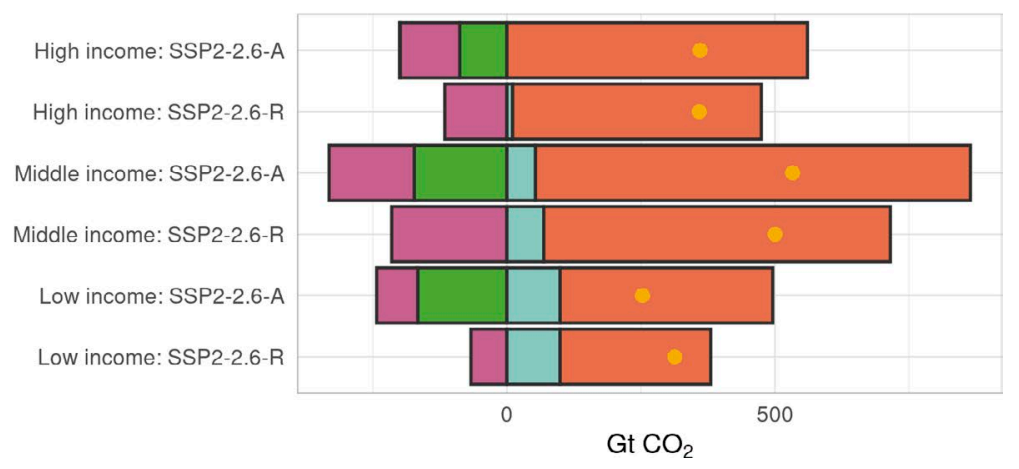

FIGURE $5 \mathrm{CO}_{2}$ emissions in baseline and mitigation pathways: (a) Annual $\mathrm{CO}_{2}$ emissions from SSP2-2.6-A, (b) cumulative $\mathrm{CO}_{2}$ emissions from 2010-2100 for all scenarios, (c) average and range of $\mathrm{CO}_{2}$ prices from 2020-2100 for all scenarios and (d) cumulative $\mathrm{CO}_{2}$ emissions from SSP2-2.6-A and SSP2-2.6-R for high, middle and low income regions [Colour figure can be viewed at wileyonlinelibrary.com]

result from afforestation and BECCS respectively. Cumulatively, negative emissions from afforestation are similar until 2100 in the stringent mitigation scenarios SSP2-2.6-A and SSP2-1.9-A with 430 and $450 \mathrm{GtCO}_{2}$ respectively, as nearly the maximum afforestation potential is utilized in these scenarios (Figure 5b). Emissions from land-use change and forestry in these scenarios persist as avoided deforestation policy is not immediately effective and because of bioenergy expansion on other natural land. In SSP2-3.4-A and SSP24.5-A, less stringent climate targets result in comparatively lower levels of carbon sequestration from afforestation of 250 and 64 $\mathrm{GtCO}_{2}$ respectively. The SSP2-6.0-A scenario does not include any afforestation as the amount of climate policy required to achieve this low ambition target is very limited: only $270 \mathrm{GtCO}_{2}$ reduction is required, which is achieved through other cheaper options.

Including afforestation as a mitigation option has a major impact on mitigation policy in other sectors. Afforestation is a relatively cheap option that reduces overall mitigation costs as indicated by lower average $\mathrm{CO}_{2}$ prices in all scenarios (Figure 5c): for example, the 2020-2100 average is 240 US $\$ / \mathrm{tCO}_{2}$ in SSP2-2.6-A compared to $430 \mathrm{US} \$ / \mathrm{tCO}_{2}$ in SSP2-2.6-R. While this means that climate policy is cheaper, it also means that less investments are made in mitigation options in the energy sector such as electrification of industry, decarbonization of transport and large-scale deployment of renewable energy sources. This implies lower ambitions in the decarbonization of sectors in energy and industry leading to $27 \%$ higher emissions in these sectors in the $2.6 \mathrm{~W} / \mathrm{m}^{2}$ afforestation scenario compared to the reference scenario.

Lower reductions in energy and industry are mirrored by increased reliance on negative emissions. In SSP2-3.4-A, SSP2-2.6-A and SSP2-1.9-A cumulative negative emissions increase by $92 \%$, $95 \%$ and $57 \%$ respectively compared to their respective reference scenarios (Figure 5b). This indicates an important risk as mitigation pathways including large-scale negative emissions that could lead to lock-in situations in sectors that are more expensive to decarbonize (Anderson \& Peters, 2016). Moreover, afforestation causes a larger share of total negative emissions to be located in lowincome regions: $31 \%$ in SSP2-2.6-A compared to $17 \%$ in SSP2-2.6-R (Figure $5 \mathrm{~d}$ ). This indicates a higher risk for implementation and permanence when mitigation occurs in regions with high investment risks and weak governance. In contrast, afforestation does reduce 
negative emissions from BECCS, which has also been criticized as a high-risk mitigation strategy (Searchinger, Beringer, \& Strong, 2017): for example, compared to their respective reference scenarios the 2.6 and $3.4 \mathrm{~W} / \mathrm{m}^{2}$ afforestation scenarios involve $13 \%$ and $26 \%$ less negative emissions from BECCS respectively.

\subsection{2 | Land use}

At moderate and high levels of $\mathrm{CO}_{2}$ prices, afforestation is an economic alternative to agriculture, and therefore agricultural area is converted to forests. The largest reductions are in the pasture land because this is the largest share of land in the baseline, is cheaper than cropland, and there is substantial potential for intensification in the livestock sector, for example, substituting feed from grass with feed from crops (Figure 6). In the more stringent scenarios also cropland for food and feed production is reduced as high food prices lead to additional intensification as well as reduced food demand. In all mitigation scenarios the land use for bioenergy increases to allow for additional climate policy, mostly at the cost of other natural lands with low carbon stocks such as savannahs.
SSP2-3.4-A, SSP2-2.6-A and SSP2-1.9-A already have substantial afforestation by 2050 (120, 440 and 470 Mha, respectively), and forests continue to expand towards 2100 (up to 740, 1,090 and 1,150 Mha, respectively). SSP2-4.5-A only shows forest expansion after 2050 as climate policy is postponed due to the low ambition target (230 Mha in 2100), while SSP2-6.0-A does not show any afforestation because $\mathrm{CO}_{2}$ prices are too low to make it profitable. SSP2-1.9-A also shows a reduction in other forests as bioenergy plantations replace managed forests in temperate and boreal regions in order to supply sufficient bioenergy to achieve the $1.9 \mathrm{~W} / \mathrm{m}^{2}$ target. Degraded forest lands are afforested in nearly all scenarios as these are relatively cheap lands.

Notable hotspots of land-use change for afforestation are South America, China, United States and Sub-Saharan Africa (Figure 4; Figure S7), because these are regions that currently have large agricultural areas as well as high potential forest growth rates. Arid regions such as Northern Africa and the Middle East show limited afforestation as forest growth rates are very low. On the other hand, for example, India also shows limited afforestation because land rents are high due to high population pressure leading to high demand for agricultural products. This limiting effect is further (a) 2010 land use

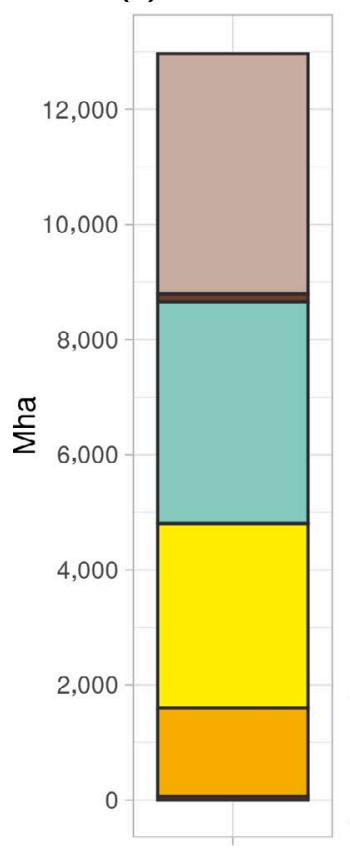

(b) 2010-2050 land-use change

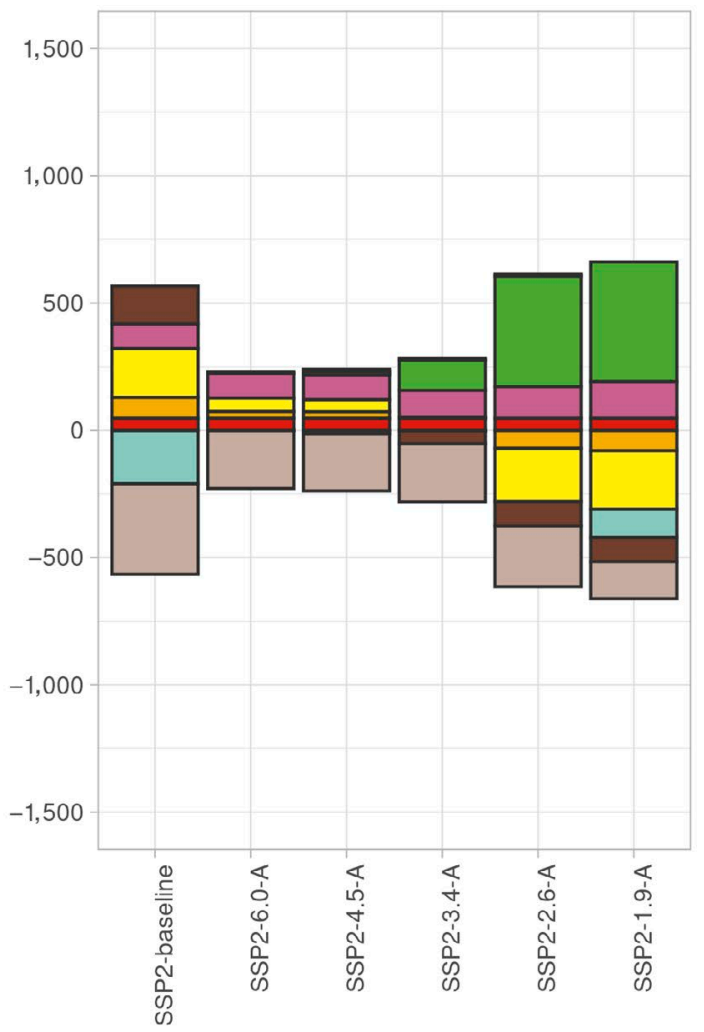

(c) 2010-2100 land-use change

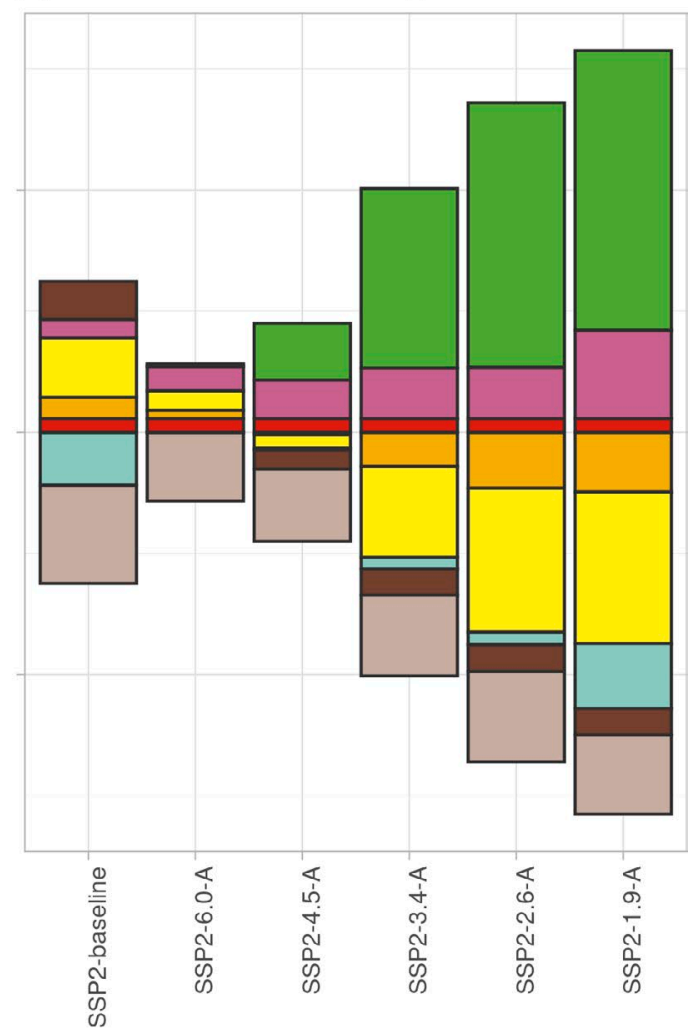

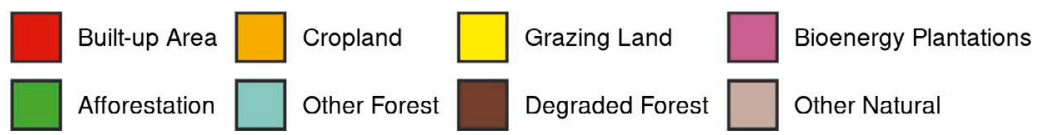

FIGURE 6 (a) Land use in 2010. Land-use change in (b) 2010-2050 and (c) 2010-2100 for the scenarios with afforestation [Colour figure can be viewed at wileyonlinelibrary.com] 
enhanced during the scenario period as the population of India is projected to continue to increase.

\subsubsection{Food security}

If afforestation is implemented in cost-optimal mitigation policy across all sectors it is likely to affect food security (Hasegawa et al., 2015, 2018), though additional measure can counteract these consequences (Doelman, Stehfest, Tabeau, \& Meijl, 2019; Fujimori et al., 2018). Here we calculate how afforestation and reductions in agricultural land could negatively affect prices and food security. Our results show increasing food prices, reduced food availability (Figures S8 and S9) and, as a consequence, negative impacts on the population at risk of hunger (Figure 7). In the baseline scenario, the population at risk of hunger is projected to decrease from 795 million in 2010 to 415 million in 2050, and to 209 million in 2100 . In the reference scenarios (SSP2-6.0/1.9-R in Figure 7) avoided deforestation policy limits this decrease to 504 million in 2050 and 275 million in 2100. Bioenergy is assumed only to occur on other lands not required for agriculture or afforestation and therefore does not affect food security (see Section 2.2). In SSP2-2.6-A, improvements in food security do not continue resulting in 716 million people at risk of hunger in 2100. This implies an additional 441 million people at risk of hunger due to afforestation for climate change mitigation.
In 2100 in the SSP2-4.5-A, SSP2-3.4-A, SSP2-1.9-A scenarios an additional 29 million, 176 million and 517 million people are at risk of hunger respectively.

Regionally, the effects differ greatly with the majority of the population at risk of hunger living in Sub-Saharan Africa and South Asia (Figure 7). In 2010, there is still a substantial risk of hunger in China, however, this decreases to near zero in 2100 in the SSP2-baseline. In stringent mitigation scenarios, the risk of hunger in China is not much affected, which is partly due to a declining population by the end of the century limiting the pressure on the food system (Figure S6). In Sub-Saharan Africa in contrast, the population at risk of hunger decreases by $56 \%$ in the baseline from 2010 to 2100 , while in SSP2-2.6-A it increases by $86 \%$. In part this is due to continued population growth in Sub-Saharan Africa as the share of the population at risk of hunger still decreases. However, also the increase in food prices, which causes a decline in food availability, has a strong effect (Figures S8 and S9).

\subsubsection{Sensitivity analysis}

To test the importance of different parameter settings we performed a sensitivity analysis (for details see Section 2.5 and Table S7; Figure 8). It is shown that the importance of the various parameters differs substantially depending on the stringency of the climate target, that is, at the level of the $\mathrm{CO}_{2}$ price. At relatively low

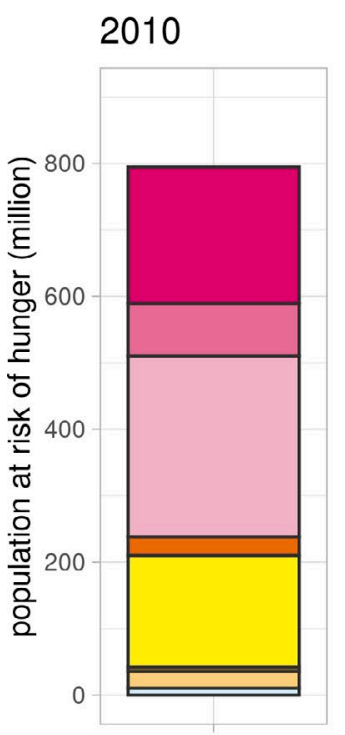

2050

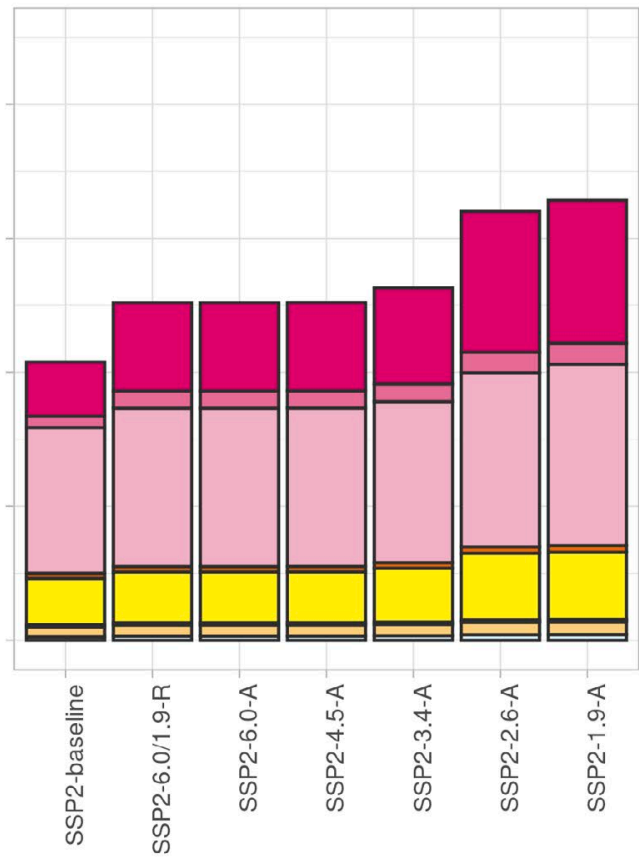

2100

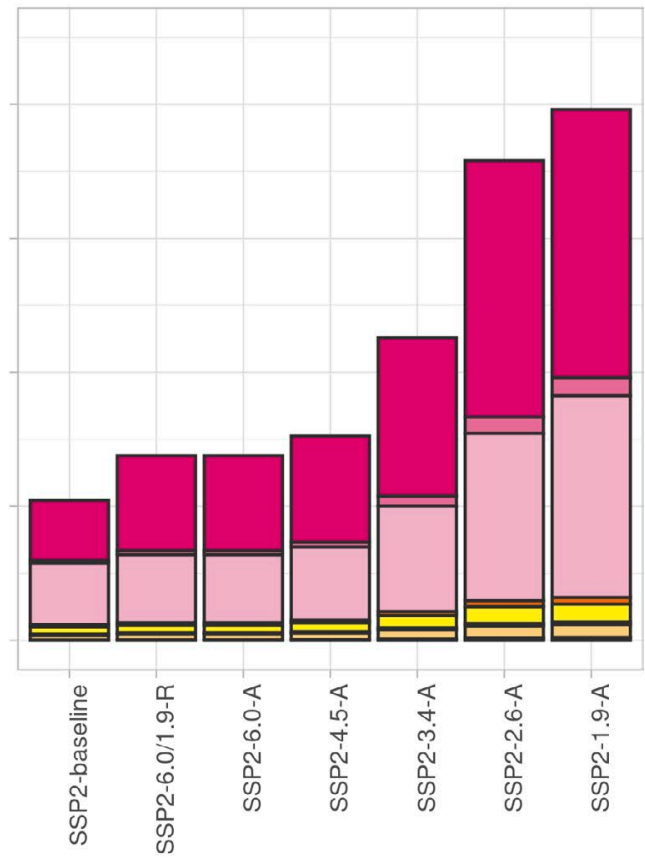

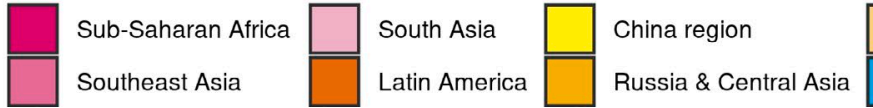

Middle East \& North Africa

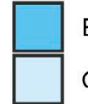

Europe

North America

Oceania Japan \& Korea

FIGURE 7 Population at risk of hunger in 10 aggregated regions in 2010, 2050 and 2100 for the baseline scenario, the reference scenarios (combined in one bar as food security effects are equal), and the afforestation scenarios [Colour figure can be viewed at wileyonlinelibrary.com] 


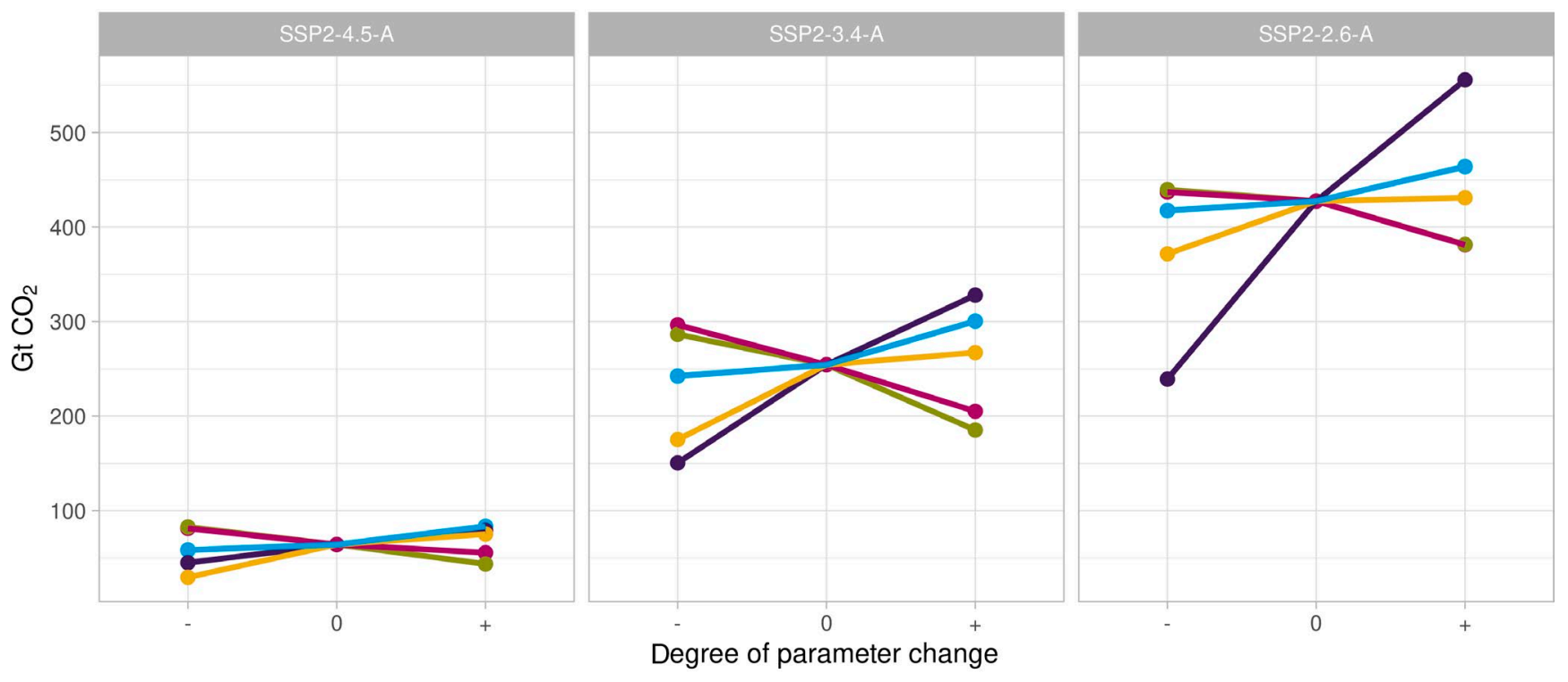

Afforestation rate $\rightarrow$ - Afforestation cost $\rightarrow$ - Discount rate $\rightarrow-$ Time horizon $\rightarrow$ - Climate

FIGURE 8 Sensitivity of cumulative carbon sequestration (2010-2100) from afforestation to selected parameter settings for three mitigation scenarios with relatively low, moderate and high $\mathrm{CO}_{2}$ prices. Settings varied for afforestation rate $(0.2 \%(-), 0.4 \%(0), 0.6 \%(+))$, afforestation costs (global low costs (Eastern Africa)(-), region-specific costs (0), global high costs (USA)(+)), discount rate (global low discount rate (USA)(-), region-specific discount rates (0), global high discount rate (USA)(+)), time horizon (10 (-), $30(0), 50(+)$ years), and climate change effects (climate change without $\mathrm{CO}_{2}$ fertilization (-), no climate change (0), climate change with $\mathrm{CO}_{2}$ fertilization(+))(for details see $\mathrm{SI}$ Table 7 ) [Colour figure can be viewed at wileyonlinelibrary.com]

or moderate $\mathrm{CO}_{2}$ prices (SSP2-4.5-A and SSP2-3.4-A: $\$ 32 / \mathrm{tCO}_{2}$ and $\$ 112 / \mathrm{tCO}_{2}$ on average in $2020-2100$, respectively) most parameters have a substantial impact: for example, a shorter time horizon leads to a strong reduction in cumulative carbon sequestration in SSP2-4.5A and SSP2-3.4-A (-54\% and $-31 \%$, respectively) due to less carbon uptake over a shorter time period implying lower expected profit. Lower afforestation costs or reduced discount rates lead to a strong increase in cumulative carbon sequestration (ranging from $13 \%$ to $29 \%$ ) as investments are profitable at lower $\mathrm{CO}_{2}$ prices. The $4.5 \mathrm{~W} / \mathrm{m}^{2}$ and $3.4 \mathrm{~W} / \mathrm{m}^{2}$ scenarios result in substantial climate change. Therefore, including the effect of changes in temperature and precipitation in combination with $\mathrm{CO}_{2}$ fertilization leads to increases in cumulative carbon sequestration ( $+30 \%$ and $+18 \%$, respectively) as the fertilization effect has a dominant positive impact on tree growth. Climate change without $\mathrm{CO}_{2}$ fertilization has a moderate negative impact on cumulative carbon sequestration ( $-5 \%$ and $-2 \%$, respectively).

In a scenario with high $\mathrm{CO}_{2}$ prices (SSP2-2.6-A: $\$ 244 / \mathrm{tCO}_{2}$ on average in 2020-2100) the maximum afforestation rate is a crucial parameter that strongly affects cumulative carbon sequestration $(-44 \%$ and $+30 \%$ for the negative and positive case, respectively). In contrast, afforestation costs and discount rates have a small effect in this scenario (ranging from $-11 \%$ to $+3 \%$ ) because the value of $\mathrm{CO}_{2}$ sequestration is so high that nearly all investments are profitable. This highlights the importance of estimating how fast carbon policy can be adopted, which is an important uncertainty in mitigation scenarios, most notably at high $\mathrm{CO}_{2}$ prices. Climate change and $\mathrm{CO}_{2}$ fertilization have a limited effect in SSP2-2.6-A (-2\% and $+9 \%$ for the negative and positive case, respectively) as the global increase in temperature is kept below $2^{\circ} \mathrm{C}$ thus preventing large effects on tree growth.

\section{4 | DISCUSSION}

In this study we show that afforestation has moderate potential for negative emissions at low $\mathrm{CO}_{2}$ prices $\left(1.5 \mathrm{Gt} \mathrm{CO}_{2}\right.$ /year in 2050 at US $\$ 50 / \mathrm{tCO}_{2}$ ) and high potential at higher $\mathrm{CO}_{2}$ prices $\left(4.9 \mathrm{Gt} \mathrm{CO}_{2}\right.$ /year in 2050 at US $\$ 200 / \mathrm{tCO}_{2}$ ). When applying afforestation in scenarios aiming for $2.6 \mathrm{~W} / \mathrm{m}^{2}$, cumulative carbon sequestration in 2100 amounts to $410 \mathrm{GtCO}_{2}$ leading to forest expansion of 1,110 Mha. This order of magnitude is similar to previous studies. Calvin et al. (2014) investigate a scenario including afforestation with the GCAM model aiming for an end-of-the-century radiative forcing of $3.7 \mathrm{~W} / \mathrm{m}^{2}$ and find an area use of approximately 1,000 Mha resulting in cumulative carbon sequestration of about $590 \mathrm{GtCO}_{2}$. Humpenöder et al. (2014) test linear carbon tax scenarios up to $\$ 194, \$ 1,165$ and $\$ 1,942$ per $\mathrm{tCO}_{2}$ with the MAgPIE model, yielding cumulative carbon sequestration from afforestation of $400 \mathrm{GtCO}_{2}, 700 \mathrm{GtCO}_{2}$ and 800 $\mathrm{GtCO}_{2}$ respectively, with area requirements of 2,000 Mha, 2,800 Mha and 3,000 Mha respectively. The SSP2 scenario aiming for $2.6 \mathrm{~W} / \mathrm{m}^{2}$ developed with the GLOBIOM model (Fricko et al., 2017) shows cumulative carbon sequestration by the year 2100 of 215 $\mathrm{GtCO}_{2}$ with an afforestation area of 830 Mha. Sathaye et al. (2006) find $176 \mathrm{GtCO}_{2}$ using 230 Mha of land with an exponential carbon tax of up to $\$ 175 / \mathrm{tCO}_{2}$ in 2100 using the GCOMAP forestry model. 
In comparison to these studies our results are in the middle of the range both for cumulative carbon sequestration and average carbon sequestration per hectare of afforested land.

Global estimates of forest growth rates vary widely (van Minnen, Strengers, Eickhout, Swart, \& Leemans, 2008). Previous studies use either a stylized growth curve (Humpenöder et al., 2014; Kyle et al., 2011) or natural forest growth from vegetation models (Krause et al., 2017). Natural forest growth in vegetation models underestimates potential growth rates of trees as no seeding, planting or management is taken into account (Braakhekke et al., 2019). This study uses forest plantations because if afforestation is actively implemented for the purpose of climate change mitigation it is likely that some form of management is implemented to enhance tree growth. To achieve high growth rates, intensive management such as planting of specialized tree species, fertilization, thinning or irrigation may be required (Laclau et al., 2005; Stape et al., 2010). However, such intensive management may impact the nutrient and hydrological cycles. Moreover, forest plantations in nonforest biomes or plantations consisting of exotic species may negatively affect biodiversity (Bremer \& Farley, 2010; Hall, Holt, Daniels, Balthazar, \& Lambin, 2012). For this reason, in this study we implement afforestation as planted forest without active management after establishment. Taking into account different management intensities is an important research priority as it affects the potential of forest-based mitigation options as well as its trade-offs with nutrient and water cycles and biodiversity.

Including afforestation as a climate change mitigation policy in stringent mitigation scenarios has important trade-offs with other policy domains. Because afforestation is relatively cheap, it is preferred in our scenarios over other more expensive policies such as electrification of industry, decarbonization of transport and largescale deployment of renewable energy sources. As a result, the average $2020-2100 \mathrm{CO}_{2}$ price required to achieve, for example, the $2.6 \mathrm{~W} / \mathrm{m}^{2}$ target is reduced by $50 \%$ in a scenario with afforestation compared to a reference scenario indicating that afforestation could reduce the overall costs of climate change mitigation. At the same time, in SSP2-2.6-A emissions from energy and industry remain substantially higher and the reliance on negative emissions to achieve the mitigation target is nearly doubled. The latter issue is a crucial risk as it is argued that dependency on future negative emissions reduces the incentive to invest in decarbonization of the energy and industry sectors today leading to lock-in situations in carbonintensive sectors (Anderson \& Peters, 2016). Also, it is argued that negative emissions could at a later stage prove infeasible or less effective, leaving society without technologies to undo the damage (Kartha \& Dooley, 2016). This risk is reinforced by our finding that a large share of the afforestation takes place in middle- and low-income regions (notably Latin America and Sub-Saharan Africa) that are currently characterized by weak governance and continued deforestation trends (Harris et al., 2012; Rochedo et al., 2018). Whether large-scale afforestation is feasible in these regions is very uncertain. An additional risk in regions with weak governance is nonpermanence, that is, that forests can be cleared again at a later stage reversing previous benefits to climate mitigation. Moreover, it is uncertain how forests will respond to climate change where a loss of carbon stocks due to increasing droughts, fire or diseases could also limit the effectiveness of afforestation (Keenan, 2015). Many of the IAM scenarios that feed into the IPCC assessments include large-scale afforestation to achieve the $2^{\circ} \mathrm{C}$ or $1.5^{\circ} \mathrm{C}$ targets. An important direction of research is the development of scenarios achieving stringent mitigation targets without high-risk strategies such as negative emissions or afforestation in the middle- and low-income regions.

Our results indicate that afforestation policy could pose a risk to food security due to reductions in agricultural land. The stringent scenarios aiming for $2.6 \mathrm{~W} / \mathrm{m}^{2}$ or $1.9 \mathrm{~W} / \mathrm{m}^{2}$ show that the population at risk of hunger remains at similar levels as in 2010 as opposed to a strong decrease in the baseline scenario. The number of people at risk of hunger in Sub-Saharan Africa and South Asia increases substantially due to afforestation. These regions are most sensitive to hunger as average food availability is relatively low causing a decrease in food availability to directly lead to an increase in number of people at risk of hunger. These findings are consistent with other studies investigating the effect of land competition from land-based mitigation such as avoided deforestation, afforestation and bioenergy and the effects of carbon pricing on agricultural emissions (Frank et al., 2017; Hasegawa et al., 2015, 2018; Kreidenweis et al., 2016; Tabeau, Meijl, Overmars, \& Stehfest, 2017; van Meijl et al., 2018), showing strong increases in food prices, reduced food consumption and increased populations at risk of hunger. These results, however, are very uncertain, especially in long-term scenarios. For one, the sensitivity of consumers to food price changes (i.e. food demand elasticity) is highly debated, with empirical evidence showing very low elasticities in high-income regions (Muhammad, Seale, Meade, \& Regmi, 2011) and some IAMs assuming zero elasticity of food demand (Kreidenweis et al., 2016). On the other hand, empirical evidence does show higher elasticities in low-income regions (Muhammad et al., 2011) and most models do include food demand elasticities (Nelson et al., 2014). Next to this, it is argued that economic models are not suitable to assess long-term projections of food demand as they are calibrated to trends in the recent past and do not take into account physical constraints (Bijl et al., 2017). Especially when assessing major shocks to the system such as those from large-scale afforestation, economic models are argued not to be suited for the major transitions that could be required. Therefore, the food security results that are presented in this paper need to be considered in light of substantial uncertainties.

Nonetheless, a recurring notion in the literature is that achieving a stable climate should not be achieved at the cost of reduced food security. This is in line with the ambitions of the Sustainable Development Goals that promote zero hunger (SDG2) as well as climate action (SDG13; UN, 2015). Therefore, when considering afforestation for climate change mitigation, it is crucial to take food security trade-offs into account, even though the quantification of the effects is associated with high uncertainty. There are many possibilities to prevent negative impacts of land-based mitigation on food security: (a) enhanced agricultural productivity 
for example, through closure of yield gaps (Doelman et al., 2019; Neumann, Verburg, Stehfest, \& Müller, 2010; van Ittersum et al., 2013), (b) dietary change leading to reduced consumption of animal products (Bajželj et al., 2014; Stehfest et al., 2009), (c) inclusive climate policies that compensate affected people (Fujimori et al., 2018), (d) or prohibiting land-based mitigation policy in regions that are sensitive to negative food security impacts (Frank et al., 2017). Furthermore, due to its relative competitiveness and the large trade-offs, it can be questioned whether afforestation and the agricultural sector should be confronted with the same $\mathrm{CO}_{2}$ price as the energy and industry sector. More likely, landbased climate policy should be stimulated through support and incentives for climate change mitigation, or managed by regulation. Still, as land use is responsible for a large share of GHG emissions and as it plays a key role in negative emission technologies, it is inevitable that land-based mitigation will have to play a role in a solution to climate change. Hence, when developing mitigation strategies involving afforestation or any other type of land-based mitigation, the trade-offs with food security as well as possible solutions need to be explicitly taken into account.

The results in this study project afforestation under ambitious mitigation policy to be economic in almost all world regions that are reasonably suitable for forest growth. The largest potential is realized in tropical regions, however, also boreal regions such as Russia and Canada show a substantial increase in forest area. The effectiveness of afforestation for climate change mitigation in boreal regions, which have substantial snow cover during part of the year, might be counteracted by biophysical climate feedbacks due to decreasing albedo. Changes in albedo can cause local warming limiting the net effect of reduced $\mathrm{CO}_{2}$ concentrations (Alkama \& Cescatti, 2016; Schaeffer et al., 2006). Conversely, expansion of forests in tropical regions can enhance evapotranspiration leading to local cooling effects thus increasing its effectiveness (Jackson et al., 2008). Including these effects in the analysis might substantially change the mitigation potential as well as land-use dynamics (Jones, Calvin, Collins, \& Edmonds, 2015; Kreidenweis et al., 2016).

A crucial parameter is the maximum afforestation rate, especially in scenarios with high $\mathrm{CO}_{2}$ prices as shown by the sensitivity analysis (see Section 3.2.4). The maximum afforestation rate is a simple assumption representing how easy agricultural land can be converted into forest. However, especially at high $\mathrm{CO}_{2}$ prices it can be argued that other mechanisms such as implementation mechanisms, local governance and adoption rates are more important determinants of the rate of afforestation (Alexander et al., 2013). Independent of the methodological approach, land conversion elasticities derived from historical data, or other mechanisms reflecting assumed rates of change or adoption of technology play a crucial role in land-use modelling.

An important assumption in this study is that agricultural land is reduced for afforestation only. This approach clearly shows the pros, cons and dynamics of afforestation and makes it possible to assess the food security and mitigation policy effects of afforestation only. However, in reality there will be competition between land use for afforestation and other land-based activities such as bioenergy production or biodiversity protection. It might be more efficient from a mitigation perspective to use forest areas for production of biomass for bioenergy while also maintaining carbon stocks (Lauri et al., 2014), or to use biomass to substitute emission-intensive materials such as concrete or steel (Leskinen et al., 2018). A comprehensive, grid-based comparison combining afforestation potentials as presented in this study and emission-factors of biomass supply chains as presented in Daioglou et al. (2017) might be able to answer this question.

In this study we have shown that moderate potential for afforestation for climate change mitigation exists at low costs (1.5 $\mathrm{GtCO}_{2} /$ year at $\$ 50 / \mathrm{tCO}_{2}$ in 2050 ) and high potential at moderate costs (4.9 $\mathrm{GtCO}_{2} /$ year at $\$ 200 / \mathrm{tCO}_{2}$ in 2050). Including afforestation cost-optimally as a mitigation option in scenarios for stringent climate targets results in a strong decrease in $\mathrm{CO}_{2}$ prices indicating that afforestation can substantially reduce overall mitigation costs. At the same time, afforestation may lead to lower mitigation ambition and lock-in situations in sectors in energy and industry. Moreover, major risks exist regarding implementation and permanence as the negative emissions are increasingly located in regions with high investment risks and weak governance. Next to this, afforestation in our $2^{\circ} \mathrm{C}$ scenario causes reductions in agricultural land leading to competition with food production. Consequently, food security could be at risk as shown by an increased population at risk of hunger, most notably in Sub-Saharan Africa and South Asia. These food security effects are a crucial trade-off of large-scale afforestation. Recent publications have presented afforestation as one of the main solutions to prevent dangerous climate change (Bastin et al., 2019; Griscom et al., 2017; Lewis et al., 2019). While afforestation indeed has substantial potential for mitigation, we show that there are also major risks and tradeoffs involved. Pathways aiming to limit climate change to $2^{\circ} \mathrm{C}$ or even $1.5^{\circ} \mathrm{C}$ need to minimize these risks and trade-offs in order to achieve mitigation sustainably.

\section{ACKNOWLEDGEMENTS}

Liesbeth de Waal and Alja Vrieling are gratefully acknowledged for their technical support. This study benefited from the funding of the European Union's Seventh Framework Programme FP7/2007-2013 under grant agreement no. 603542 (LUC4C).

\section{CONFLICT OF INTEREST}

The authors declare no conflict of interest.

\section{ORCID}

Jonathan C. Doelman (iD https://orcid.org/0000-0002-6842-573X Elke Stehfest iD https://orcid.org/0000-0003-3016-2679 Detlef P. van Vuuren iD https://orcid.org/0000-0003-0398-2831 Andries F. Hof (iD https://orcid.org/0000-0002-7568-5038 David E. H. J. Gernaat iD https://orcid.org/0000-0003-4994-1453 Willem-Jan van Zeist iD https://orcid.org/0000-0002-6371-8509 Vassilis Daioglou (iD https://orcid.org/0000-0002-6028-352X Hans van Meijl (ID) https://orcid.org/0000-0002-2455-6869 Paul L. Lucas (iD https://orcid.org/0000-0003-0292-7830 


\section{REFERENCES}

Alexander, P., Moran, D., Rounsevell, M. D., \& Smith, P. (2013). Modelling the perennial energy crop market: The role of spatial diffusion. Journal of the Royal Society Interface, 10, 20130656.

Alkama, R., \& Cescatti, A. (2016). Biophysical climate impacts of recent changes in global forest cover. Science, 351, 600-604. https://doi. org/10.1126/science.aac8083

Anderson, K., \& Peters, G. (2016). The trouble with negative emissions. Science, 354, 182-183.

Azar, C., Lindgren, K., Obersteiner, M., Riahi, K., Van Vuuren, D. P., Den Elzen, K. M. G., ... Larson, E. D. (2010). The feasibility of low $\mathrm{CO}_{2}$ concentration targets and the role of bio-energy with carbon capture and storage (BECCS). Climatic Change, 100, 195-202.

Bajželj, B., Richards, K. S., Allwood, J. M., Smith, P., Dennis, J. S., Curmi, E., \& Gilligan, C. A. (2014). Importance of food-demand management for climate mitigation. Nature Climate Change, 4, 924-929.

Bastin, J.-F., Finegold, Y., Garcia, C., Mollicone, D., Rezende, M., Routh, D., ... Crowther, T. W. (2019). The global tree restoration potential., Science, 365, 76-79. https://doi.org/10.1126/science.aax0848

Benítez, P. C., McCallum, I., Obersteiner, M., \& Yamagata, Y. (2007). Global potential for carbon sequestration: Geographical distribution, country risk and policy implications. Ecological Economics, 60, 572583. https://doi.org/10.1016/j.ecolecon.2005.12.015

Bijl, D. L., Bogaart, P. W., Dekker, S. C., Stehfest, E., De Vries, B. J., \& Van Vuuren, D. P. (2017). A physically-based model of long-term food demand. Global Environmental Change, 45, 47-62. https://doi. org/10.1016/j.gloenvcha.2017.04.003

Bondeau, A., Smith, P. C., Zaehle, S., Schaphoff, S., Lucht, W., Cramer, W., ... Smith, B. (2007). Modelling the role of agriculture for the 20th century global terrestrial carbon balance. Global Change Biology, 13, 679-706.

Braakhekke, M. C., Doelman, J. C., Baas, P., Müller, C., Schaphoff, S., Stehfest, E., \& Van Vuuren, D. P. (2019). Modeling forest plantations for carbon uptake with the LPJmL dynamic global vegetation model. Earth System Dynamics, 10, 617-630. https://doi.org/10.5194/ esd-10-617-2019

Bremer, L. L., \& Farley, K. A. (2010). Does plantation forestry restore biodiversity or create green deserts? A synthesis of the effects of land-use transitions on plant species richness. Biodiversity and Conservation, 19,3893-3915.https://doi.org/10.1007/s10531-0109936-4

Busch, J., Engelmann, J., Cook-Patton, S. C., Griscom, B. W., Kroeger, T., Possingham, H., \& Shyamsundar, P. (2019). Potential for low-cost carbon dioxide removal through tropical reforestation. Nature Climate Change, 9, 463-466.

Calvin, K., Wise, M., Kyle, P., Patel, P., Clarke, L., \& Edmonds, J. (2014). Trade-offs of different land and bioenergy policies on the path to achieving climate targets. Climatic Change, 123, 691-704. https://doi. org/10.1007/s10584-013-0897-y

Canadell, J. G., \& Raupach, M. R. (2008). Managing forests for climate change mitigation. Science, 320, 1456-1457. https://doi.org/10.1126/ science. 1155458

Clarke, D., McGugin, S., Schmirer, G., \& Towers, S. (2008). Project plan for carbon sequestration through afforestation in the lower Mississippi alluvial valley. Laboratory for Sustainable Business, Massachusetts Institute of Technology.

Clarke, L., Jiang, K., Akimoto, K., Babiker, M., Blanford, G., Fisher-Vanden, K., ...Löschel, A. (2014). Assessing transformation pathways.

Daioglou, V., Doelman, J. C., Stehfest, E., Müller, C., Wicke, B., Faaij, A., \& Van Vuuren, D. P. (2017). Greenhouse gas emission curves for advanced biofuel supply chains. Nature Climate Change, 7, 920.

Daioglou, V., Doelman, J. C., Wicke, B., Faaij, A., \& Van Vuuren, D. P. (2019). Integrated assessment of biomass supply and demand in climate change mitigation scenarios. Global Environmental Change, 54, 88-101. https://doi.org/10.1016/j.gloenvcha.2018.11.012
Den Elzen, M. G., Lucas, P. L., \& Van Vuuren, D. P. (2008). Regional abatement action and costs under allocation schemes for emission allowances for achieving low $\mathrm{CO}_{2}$-equivalent concentrations. Climatic Change, 90, 243-268.

Doelman, J. C., Stehfest, E., Tabeau, A., \& van Meijl, H. (2019). Making the Paris agreement climate targets consistent with food security objectives. Global Food Security, 23, 93-103. https://doi.org/10.1016/ j.gfs.2019.04.003

Doelman, J. C., Stehfest, E., Tabeau, A., van Meijl, H., Lassaletta, L., Gernaat, D. E. H. J., ... van Vuuren, D. P. (2018). Exploring SSP landuse dynamics using the IMAGE model: Regional and gridded scenarios of land-use change and land-based climate change mitigation. Global Environmental Change, 48, 119-135. https://doi.org/10.1016/ j.gloenvcha.2017.11.014

Dutschke, M. (2001). Permanence of CDM forests or non-permanence of land use related carbon credits? HWWA discussion paper.

FAO. (2008). Methodology for the measurement of food deprivation: Updating the minimum dietary energy requirements. Rome, Italy: FAO.

FAO. (2018). Global forest resource assessment 2020 - Terms and definitions. Rome, Italy: FAO.

FAOSTAT. (2017). Food and agricultural organization of the United Nations [Online]. Retrieved from www.fao.org/faostat

Frank, S., Havlík, P., Soussana, J.-F., Levesque, A., Valin, H., Wollenberg, E., ... Herrero, M. (2017). Reducing greenhouse gas emissions in agriculture without compromising food security? Environmental Research Letters, 12, 105004.

Fricko, O., Havlik, P., Rogelj, J., Klimont, Z., Gusti, M., Johnson, N., ... Amann, M. (2017). The marker quantification of the Shared Socioeconomic Pathway 2: A middle-of-the-road scenario for the 21st century. Global Environmental Change, 42, 251-267. https://doi. org/10.1016/j.gloenvcha.2016.06.004

Fujimori, S., Hasegawa, T., Rogelj, J., Su, X., Havlik, P., Krey, V., ... Riahi, K. (2018). Inclusive climate change mitigation and food security policy under $1.5^{\circ} \mathrm{C}$ climate goal. Environmental Research Letters, 13, 074033.

Griscom, B. W., Adams, J., Ellis, P. W., Houghton, R. A., Lomax, G., Miteva, D. A., ... Fargione, J. (2017). Natural climate solutions. Proceedings of the National Academy of Sciences of the United States of America. 114, 11645-11650. https://doi.org/10.1073/pnas.1710465114

Hall, J. M., van Holt, T., Daniels, A. E., Balthazar, V., \& Lambin, E. F. (2012). Trade-offs between tree cover, carbon storage and floristic biodiversity in reforesting landscapes. Landscape Ecology, 27, 1135-1147.

Harris, N. L., Brown, S., Hagen, S. C., Saatchi, S. S., Petrova, S., Salas, W., ... Lotsch, A. (2012). Baseline map of carbon emissions from deforestation in tropical regions. Science, 336, 1573-1576. https://doi. org/10.1126/science.1217962

Hasegawa, T., Fujimori, S., Havlík, P., Valin, H., Bodirsky, B. L., Doelman, J. C., Mason-D'croz, D., ... Witzke, P. (2018). Risk of increased food insecurity under stringent global climate change mitigation policy. Nature Climate Change, 8, 699-703.

Hasegawa, T., Fujimori, S., Shin, Y., Tanaka, A., Takahashi, K., \& Masui, T. (2015). Consequence of climate mitigation on the risk of hunger. Environmental Science \& Technology, 49, 7245-7253.

Hertel, T. (2012). Global applied general equilibrium analysis using the GTAP framework. Center for Global Trade Analysis, Department of Agricultural Economics, Purdue University.

Hoogwijk, M., Faaij, A., de Vries, B., \& Turkenburg, W. (2009). Exploration of regional and global cost-supply curves of biomass energy from short-rotation crops at abandoned cropland and rest land under four IPCC SRES land-use scenarios. Biomass and Bioenergy, 33, 26-43. https://doi.org/10.1016/j.biomb ioe.2008.04.005

Humpenöder, F., Popp, A., Dietrich, J. P., Klein, D., Lotze-Campen, H., Bonsch, M., ... Müller, C. (2014). Investigating afforestation and bioenergy CCS as climate change mitigation strategies. Environmental Research Letters, 9, 064029. 
Iyer, G. C., Clarke, L. E., Edmonds, J. A., Flannery, B. P., Hultman, N. E., McJeon, H. C., \& Victor, D. G. (2015). Improved representation of investment decisions in assessments of $\mathrm{CO}_{2}$ mitigation. Nature Climate Change, 5, 436.

Jackson, R. B., Randerson, J. T., Canadell, J. G., Anderson, R. G., Avissar, R., Baldocchi, D. D., ... Field, C. B. (2008). Protecting climate with forests. Environmental Research Letters, 3, 044006.

Jones, A. D., Calvin, K. V., Collins, W. D., \& Edmonds, J. (2015). Accounting for radiative forcing from albedo change in future global land-use scenarios. Climatic Change, 131, 691-703. https://doi.org/10.1007/ s10584-015-1411-5

Kartha, S., \& Dooley, K. (2016). The risks of relying on tomorrow's 'negative emissions' to guide today's mitigation action. Stockholm Environmental Institute, Somerville, Aug.

Keenan, R. J. (2015). Climate change impacts and adaptation in forest management: A review. Annals of Forest Science, 72, 145-167. https:// doi.org/10.1007/s13595-014-0446-5

Kindermann, G., Obersteiner, M., Sohngen, B., Sathaye, J., Andrasko, K., Rametsteiner, E., ... Beach, R. (2008). Global cost estimates of reducing carbon emissions through avoided deforestation. Proceedings of the National Academy of Sciences of the United States of America, 105, 10302-10307. https://doi.org/10.1073/pnas.0710616105

Krause, A., Pugh, T. A., Bayer, A. D., Doelman, J. C., Humpenöder, F., Anthoni, P., ... Stehfest, E. (2017). Global consequences of afforestation and bioenergy cultivation on ecosystem service indicators. Biogeosciences, 14,4829-4850. https://doi.org/10.5194/bg-14-48292017

Kreidenweis, U., Humpenöder, F., Stevanović, M., Bodirsky, B. L., Kriegler, E., Lotze-Campen, H., \& Popp, A. (2016). Afforestation to mitigate climate change: Impacts on food prices under consideration of albedo effects. Environmental Research Letters, 11, 085001.

Kyle, G. P., Luckow, P., Calvin, K. V., Emanuel, W. R., Nathan, M., \& Zhou, Y. (2011). GCAM 3.0 agriculture and land use: data sources and methods. Richland, WA: Pacific Northwest National Laboratory (PNNL).

Laclau, J.-P., Ranger, J., Deleporte, P., Nouvellon, Y., Saint-André, L., Marlet, S., \& Bouillet, J.-P. (2005). Nutrient cycling in a clonal stand of Eucalyptus and an adjacent savanna ecosystem in Congo: 3. Inputoutput budgets and consequences for the sustainability of the plantations. Forest Ecology and Management, 210, 375-391.

Lauri, P., Havlík, P., Kindermann, G., Forsell, N., Böttcher, H., \& Obersteiner, M. (2014). Woody biomass energy potential in 2050. Energy Policy, 66, 19-31. https://doi.org/10.1016/j.enpol.2013.11.033

Leskinen, P., Cardellini, G., González-García, S., Hurmekoski, E., Sathre, R., Seppälä, J., ... Verkerk, P. J. (2018). Substitution effects of woodbased products in climate change mitigation. From Science to Policy, 7. https://doi.org/10.36333/fs07

Lewis, S. L., Wheeler, C. E., Mitchard, E. T., \& Koch, A. (2019). Restoring natural forests is the best way to remove atmospheric carbon. Nature, 568(7750), 25-28. https://doi.org/10.1038/d41586-019-01026-8

Lucas, P. L., Hilderink, H. B. M., Janssen, P. H. M., Kc, S., van Vuuren, D. P., \& Niessen, L. (2019). Future impacts of environmental factors on achieving the SDG target on child mortality-A synergistic assessment. Global Environmental Change, 57, 101925.

Meinshausen, M., Raper, S. C. B., \& Wigley, T. M. L. (2011). Emulating coupled atmosphere-ocean and carbon cycle models with a simpler model, MAGICC6 - Part 1: Model description and calibration. Atmospheric Chemistry and Physics, 11, 1417-1456.

Muhammad, A., Seale, J. L., Meade, B., \& Regmi, A. (2011). International evidence on food consumption patterns: An update using 2005 international comparison program data. SSRN Electronic Journal, https:// doi.org/10.2139/ssrn.2114337

Nelson, G. C., Valin, H., Sands, R. D., Havlik, P., Ahammad, H., Deryng, D., ... Willenbockel, D. (2014). Climate change effects on agriculture: Economic responses to biophysical shocks. Proceedings of the
National Academy of Sciences of the United States of America, 111, 3274-3279. https://doi.org/10.1073/pnas.1222465110

Neumann, K., Verburg, P. H., Stehfest, E., \& Müller, C. (2010). The yield gap of global grain production: A spatial analysis. Agricultural Systems, 103, 316-326. https://doi.org/10.1016/j.agsy.2010.02.004

Overmars, K. P., Stehfest, E., Tabeau, A., van Meijl, H., Beltrán, A. M., \& Kram, T. (2014). Estimating the opportunity costs of reducing carbon dioxide emissions via avoided deforestation, using integrated assessment modelling. Land Use Policy, 41, 45-60.

Riahi, K., van Vuuren, D. P., Kriegler, E., Edmonds, J., O'Neill, B. C., Fujimori, S., ... Fricko, O. (2017). The shared socioeconomic pathways and their energy, land use, and greenhouse gas emissions implications: An overview. Global Environmental Change, 42, 153-168. https:// doi.org/10.1016/j.gloenvcha.2016.05.009

Rochedo, P. R. R., Soares-Filho, B., Schaeffer, R., Viola, E., Szklo, A., Lucena, A. F. P., ... Rathmann, R. (2018). The threat of political bargaining to climate mitigation in Brazil. Nature Climate Change, 8 , 695-698.

Rogelj, J., Hare, W., Lowe, J., van Vuuren, D. P., Riahi, K., Matthews, B., ... Meinshausen, M. (2011). Emission pathways consistent with a 2? C global temperature limit. Nature Climate Change, 1, 413-418.

Rogelj, J., Popp, A., Calvin, K. V., Luderer, G., Emmerling, J., Gernaat, D., ... Marangoni, G. (2018). Scenarios towards limiting global mean temperature increase below $1.5^{\circ} \mathrm{C}$. Nature Climate Change, 8, 325-332.

Sathaye, J., Makundi, W., Dale, L., Chan, P., \& Andrasko, K. (2006). GHG mitigation potential, costs and benefits in global forests: A dynamic partial equilibrium approach. The Energy Journal, 127-162. https:// doi.org/10.5547/ISSN0195-6574-EJ-VoISI2006-NoSI3-7

Schaeffer, M., Eickhout, B., Hoogwijk, M., Strengers, B., van Vuuren, D., Leemans, R., \& Opsteegh, T. (2006). $\mathrm{CO}_{2}$ and albedo climate impacts of extratropical carbon and biomass plantations. Global Biogeochemical Cycles, 20. https://doi.org/10.1029/2005GB002581

Searchinger, T. D., Beringer, T., \& Strong, A. (2017). Does the world have low-carbon bioenergy potential from the dedicated use of land? Energy Policy, 110, 434-446. https://doi.org/10.1016/ j.enpol.2017.08.016

Shabman, L., Zepp, L., Wainger, L., \& King, D. (2002). Incentives for reforestation of agricultural land: What will a market for carbon sequestration credits contribute? American Journal of Alternative Agriculture 17, 116-124. https://doi.org/10.1079/AJAA200213

Sitch, S., Smith, B., Prentice, I. C., Arneth, A., Bondeau, A., Cramer, W., ... Sykes, M. T. (2003). Evaluation of ecosystem dynamics, plant geography and terrestrial carbon cycling in the LPJ dynamic global vegetation model. Global Change Biology, 9, 161-185. https://doi. org/10.1046/j.1365-2486.2003.00569.x

Smith, P. (2013). Chapter 11: Agriculture, forestry and other land use (AFOLU). IPCC WGIII AR5.

Sohngen, B., \& Sedjo, R. (2006). Carbon sequestration in global forests under different carbon price regimes. The Energy Journal, 109-126.

Stape, J. L., Binkley, D., Ryan, M. G., Fonseca, S., Loos, R. A., Takahashi, E. N., ... Azevedo, M. R. (2010). The Brazil eucalyptus potential productivity project: Influence of water, nutrients and stand uniformity on wood production. Forest Ecology and Management, 259, 1684-1694. https://doi.org/10.1016/j.foreco.2010.01.012

Stehfest, E., Bouwman, L., van Vuuren, D. P., den Elzen, M. G. J., Eickhout, B., \& Kabat, P. (2009). Climate benefits of changing diet. Climatic Change, 95, 83-102. https://doi.org/10.1007/s10584-008-9534-6

Stehfest, E., van Vuuren, D., Kram, T., Bouwman, L., Alkemade, R., Bakkenes, M., ... Prins, A. (2014). Integrated Assessment of Global Environmental Change with IMAGE 3.0. Model description and policy applications. The Hague, the Netherlands: PBL Netherlands Environmental Assessment Agency.

Strengers, B. J., van Minnen, J. G., \& Eickhout, B. (2007). The role of carbon plantations in mitigating climate change: Potentials and costs. Climatic Change, 88, 343-366. 
Tabeau, A., van Meijl, H., Overmars, K. P., \& Stehfest, E. (2017). REDD policy impacts on the agri-food sector and food security. Food Policy, 66, 73-87. https://doi.org/10.1016/j.foodpol.2016.11. 006

UN, G. A. (2015). Transforming our world: The 2030 agenda for sustainable development. A/RES/70/1, 21 October.

van Ittersum, M. K., Cassman, K. G., Grassini, P., Wolf, J., Tittonell, P., \& Hochman, Z. (2013). Yield gap analysis with local to global relevance-A review. Field Crops Research, 143, 4-17.

van Meijl, H., Havlik, P., Lotze-Campen, H., Stehfest, E., Witzke, P., Domínguez, I. P., ... Fellmann, T. (2018). Comparing impacts of climate change and mitigation on global agriculture by 2050 . Environmental Research Letters, 13, 064021.

van Minnen, J. G., Strengers, B. J., Eickhout, B., Swart, R. J., \& Leemans, R. (2008). Quantifying the effectiveness of climate change mitigation through forest plantations and carbon sequestration with an integrated land-use model. Carbon Balance and Managment, 3, 1.

van Vuuren, D. P. (2007). Energy systems and climate policy-long-term scenarios for an uncertain future.

van Vuuren, D. P., Deetman, S., van Vliet, J., van den Berg, M., van Ruijven, B. J., \& Koelbl, B. (2013). The role of negative $\mathrm{CO}_{2}$ emissions for reaching $2{ }^{\circ} \mathrm{C}-$ Insights from integrated assessment modelling. Climatic Change, 118, 15-27.

van Vuuren, D. P., Edmonds, J., Kainuma, M., Riahi, K., Thomson, A., Hibbard, K., ... Rose, S. K. (2011). The representative concentration pathways: An overview. Climatic Change, 109, 5-31.

van Vuuren, D. P., Hof, A. F., van Sluisveld, M. A., \& Riahi, K. (2017). Open discussion of negative emissions is urgently needed. Nature Energy, 2, 902.

van Vuuren, D. P., Riahi, K., Moss, R., Edmonds, J., Thomson, A., Nakicenovic, N., ... Arnell, N. (2012). A proposal for a new scenario framework to support research and assessment in different climate research communities. Global Environmental Change, 22, 21-35. https ://doi.org/10.1016/j.gloenvcha.2011.08.002

van Vuuren, D. P., Stehfest, E., Gernaat, D. E., Berg, M., Bijl, D. L., Boer, H. S., ... Harmsen, M. (2018). Alternative pathways to the $1.5^{\circ} \mathrm{C}$ target reduce the need for negative emission technologies. Nature Climate Change, 8, 391-397.

van Vuuren, D. P., Stehfest, E., Gernaat, D. E., Doelman, J. C., van den Berg, M., Harmsen, M., ... Edelenbosch, O. Y. (2017). Energy, landuse and greenhouse gas emissions trajectories under a green growth paradigm. Global Environmental Change, 42, 237-250.

Winsten, J., Walker, S., Brown, S., \& Grimland, S. (2011). Estimating carbon supply curves from afforestation of agricultural land in the Northeastern U.S. Mitigation and Adaptation Strategies for Global Change, 16, 925-942.

Woltjer, G. B., \& Kuiper, M. H. (2014). The MAGNET model: Module description. Wageningen, the Netherlands: LEI Wageningen UR.

Woltjer, G. B., Kuiper, M., Kavallari, A., van Meijl, H., Powell, J., Rutten, M., ... Tabeau, A. (2014). The MAGNET model: Module description. Wageningen, the Netherlands: LEI Wageningen UR.

\section{SUPPORTING INFORMATION}

Additional supporting information may be found online in the Supporting Information section.

How to cite this article: Doelman JC, Stehfest E, van Vuuren DP, et al. Afforestation for climate change mitigation: Potentials, risks and trade-offs. Glob Change Biol. 2020;26:1576-1591. https://doi.org/10.1111/gcb.14887 